\title{
Post-collisional magmatism: Crustal growth not identified by zircon Hf-O isotopes
}

\author{
Simon Couziniée ${ }^{\mathrm{a}, \mathrm{b}, *}$, Oscar Laurent ${ }^{\mathrm{c}, \mathrm{d}}$, Jean-François Moyen ${ }^{\mathrm{a}}$, Armin Zeh ${ }^{\mathrm{c}, \mathrm{e}}$, \\ Pierre Bouilhol ${ }^{\mathrm{f}}$, Arnaud Villaros ${ }^{\mathrm{g}, \mathrm{h}, \mathrm{i}}$ \\ ${ }^{a}$ Univ. Lyon, UJM-Saint-Etienne, UBP, CNRS, IRD, Laboratoire Magmas et Volcans UMR 6524, F-42023 Saint Etienne, France \\ b University of Stellenbosch, Department of Earth Sciences, Private Bag X1, 7602 Matieland, South Africa \\ c J.W. Goethe Universität, Institut für Geowissenschaften, Altenhöferallee 1, D-60438 Frankfurt am Main, Germany \\ d Université de Liège, Département de Géologie B20, Quartier Agora, allée du six Août 12, B-4000 Liège, Belgium \\ e Karlsruher Institut für Technologie, Campus Süd, Institut für Angewandte Geowissenschaften, Abteilung Mineralogie und Petrologie, Kaiserstrasse 12, \\ D-76131 Karlsruhe, Germany \\ ${ }^{\mathrm{f}}$ Department of Earth Sciences, Durham University, Science Labs, Durham DH13LE, United Kingdom \\ g Université d'Orléans, ISTO, UMR 7327, 45071, Orléans, France \\ h CNRS, ISTO, UMR 7327, F-45071 Orléans, France \\ i BRGM, ISTO, UMR 7327, BP 36009, 45060 Orléans, France
}

\section{A R T I C L E I N F O}

\section{Article history:}

Received 9 March 2016

Received in revised form 19 September

2016

Accepted 21 September 2016

Available online $\mathrm{xxxx}$

Editor: A. Yin

\section{Keywords:}

post-collisional mafic magmas

crustal growth

zircon

Lu-Hf isotopes

$\mathrm{O}$ isotopes

metasomatized mantle

\begin{abstract}
A B S T R A C T
The combination of $\mathrm{U}-\mathrm{Pb}, \mathrm{Lu}-\mathrm{Hf}$ and $\mathrm{O}$ isotopic analyses in global zircon databases has recently been used to constrain continental crustal growth and evolution. To identify crust-forming events, these studies rely on the assumption that new crust is formed from depleted mantle sources. In contrast, this work suggests that post-collisional mafic magmas and their derivatives represent a non-negligible contribution to crustal growth, despite having zircons with "crust-like" $\mathrm{Hf}-\mathrm{O}$ isotopic characteristics. We address this paradox and its implications for crustal evolution on the basis of a case study from the Variscan French Massif Central (FMC). The late stages of continental collisions are systematically marked by the emplacement of peculiar mafic magmas, rich in both compatible ( $\mathrm{Fe}, \mathrm{Mg}, \mathrm{Ni}, \mathrm{Cr}$ ) and incompatible elements ( $\mathrm{K}_{2} \mathrm{O}$, HFSE, LREE) and displaying crust-like trace element patterns. This dual signature is best explained by melting of phlogopite- (and/or amphibole-) bearing peridotite, formed by contamination of the mantle by limited amounts (10-20\%) of crustal material during continental subduction shortly preceding collision. Mass balance constraints show that in melts derived from such a hybrid source, $62-85 \%$ of the bulk mass is provided by the mantle component, whereas incompatible trace elements are dominantly crustal in origin. Thereby, post-collisional mafic magmas represent significant additions to the crust, whilst their zircons have "crustal" isotope signatures (e.g. $-2<\varepsilon \mathrm{Hf}_{\mathrm{t}}<-9$ and $+6.4<\delta^{18} \mathrm{O}<$ $+10 \%$ in the FMC). Because post-collisional mafic magmas are (i) ubiquitous since the late Archean; (ii) the parental magmas of voluminous granitoid suites; and (iii) selectively preserved in the geological record, zircons crystallized from such magmas (and any material derived from their differentiation or reworking) bias the crustal growth record of global zircon $\mathrm{Hf}-\mathrm{O}$ isotopic datasets towards ancient crust formation and, specifically, may lead to an under-estimation of crustal growth rates since the late Archean.
\end{abstract}

\section{Introduction}

The formation of the continental crust is a major consequence of planetary differentiation and played a key role in the evolu-

\footnotetext{
* Corresponding author at: Univ. Lyon, UJM-Saint-Etienne, UBP, CNRS, IRD, Laboratoire Magmas et Volcans UMR 6524, F-42023 Saint Etienne, France.

E-mail addresses: simon.couzinie@univ-st-etienne.fr, simon.couzinie@ens-lyon.org (S. Couzinié).
}

tion of climate and life (Campbell and Allen, 2008; Lowe and Tice, 2004). The mechanisms and rates of continental formation are therefore fundamental parameters to be addressed and have long been a matter of controversy (Arndt, 2013; Hawkesworth et al., 2010). The formation of new continental crust requires two fundamental conditions to be fulfilled, regardless of the tectonic setting in which it takes place: (1) genesis (and differentiation) of mantle-derived igneous material; and (2) long-term incorporation and preservation of this material into the pre-existing continen- 
Table 1

Summary of the main documented occurrences of PCMM in the geological record.

\begin{tabular}{|c|c|c|c|c|}
\hline Orogen & Age of PCMM & Specific nomenclature & Differentiates & Proposed references \\
\hline Late Archean terranes & 2950 to $2500 \mathrm{Ma}$ & Sanukitoid & Sanukitoid suite & Laurent et al. (2014a) \\
\hline Svecofennian (Scandinavia) & $1800 \mathrm{Ma}$ & Ladogite, Nevoite & Post-kinematic granitoids & Rutanen et al. (2011) \\
\hline Pan-African & $620-560 \mathrm{Ma}$ & Sanukitoid & $\begin{array}{l}\text { High-K calc-alkaline (HKCA) } \\
\text { granitoids }\end{array}$ & Liégeois et al. (1998) \\
\hline Ross (Antarctica) & $515-500 \mathrm{Ma}$ & No specific name given & No specific name given & Hagen-Peter et al. (2015) \\
\hline East Kunlun (China) & c. $450 \mathrm{Ma}$ & Appinite & Not described & Xiong et al. (2015) \\
\hline Caledonian & 425-410 Ma & Appinite & High Ba-Sr granites & Fowler and Rollinson (2012) \\
\hline Central Asian Orogenic Belt & $\begin{array}{l}425 \text { to } 300 \mathrm{Ma} \\
\text { (several pulses) }\end{array}$ & Sanukitoid & Not described & Yin et al. (2015) \\
\hline Variscan & $335-300 \mathrm{Ma}$ & $\begin{array}{l}\text { Vaugnerite, Durbachite, } \\
\text { Redwitzite, Appinite }\end{array}$ & $\begin{array}{l}\text { Felsic durbachites; K-rich calc-alkaline } \\
\text { granitoids (KCG) }\end{array}$ & $\begin{array}{l}\text { Moyen et al. (in press); } \\
\text { Holub (1997); von Raumer } \\
\text { et al. (2014) }\end{array}$ \\
\hline $\begin{array}{l}\text { North China Block assembly } \\
\text { (Dabie-Sulu orogen...) }\end{array}$ & $\begin{array}{l}320 \text { to } 115 \mathrm{Ma} \\
\text { (several pulses) }\end{array}$ & Appinite & Post-collisional granitoids & Zhao et al. (2013) \\
\hline Himalaya & 20 to $3 \mathrm{Ma}$ & $\begin{array}{l}\text { Post-collisional (ultra)potassic } \\
\text { magmas }\end{array}$ & (Ultra)potassic silicic magmas & Williams et al. (2004) \\
\hline
\end{tabular}

tal volume (Condie et al., 2011; Hawkesworth et al., 2009; Stern and Scholl, 2010). Radiogenic isotope systems like $\mathrm{Rb} / \mathrm{Sr}, \mathrm{Sm} / \mathrm{Nd}$ and $\mathrm{Lu} / \mathrm{Hf}$ are extensively used to track crust-forming events, and it is consensually assumed that the radiogenic isotope composition of newly-formed crust is identical to that of the depleted mantle (DM) (McCulloch and Wasserburg, 1978; Patchett et al., 1982; Vervoort and Blichert-Toft, 1999).

In this respect, the study of continental growth recently benefited from advances in analytical techniques enabling in situ isotopic measurements in zircon, a widespread accessory mineral of continental igneous rocks. Because zircon is able to survive several metamorphic, igneous and sedimentary cycles and contains a wealth of isotopic information ( $\mathrm{U}-\mathrm{Pb}, \mathrm{Lu}-\mathrm{Hf}, \mathrm{O}$ isotopes), it represents an outstanding archive of crust formation and evolution (Bouilhol et al., 2013; Bouilhol et al., 2011; Condie et al., 2011; Roberts and Spencer, 2015). The analyses of U-Pb and Lu-Hf isotope compositions within the same zircon give access to both the age and the Hf isotopic signature of the magma in which it crystallized (Griffin et al., 2002; Woodhead et al., 2004). The latter is converted into a crustal residence ("model") age corresponding to the time at which the crustal source of the zirconhosting magma would have been extracted from the DM (Kemp et al., 2006). The coupled analysis of 0 isotopes has been proposed to discriminate between zircons crystallized from magmas having a sedimentary source $\left(\delta^{18} \mathrm{O}>6.5 \%\right.$; Kemp et al., 2006; Valley et al., 1998) and thus, meaningless "mixed" model ages (Arndt and Goldstein, 1987), from those having an ultimately mantle-derived source $\left(\delta^{18} \mathrm{O} \sim 5.5 \pm 1.0 \%\right.$ ) and supposed to yield reliable model ages (Hawkesworth and Kemp, 2006). Accordingly, statistical analyses of $\mathrm{U}-\mathrm{Pb}-\mathrm{Hf}(-\mathrm{O})$ isotopic databases from both igneous and detrital zircons were extensively used to quantify the timing, amount and mechanisms of continental crust formation through time (Belousova et al., 2010; Dhuime et al., 2012; Hawkesworth and Kemp, 2006; Lancaster et al., 2011).

Nevertheless, the reliability of this approach has recently been questioned, especially because incorporation in the mantle of continental crust-derived materials (subducted supracrustal lithologies and/or any fluid/melt generated from them) may significantly blur the zircon $\mathrm{Hf}-\mathrm{O}$ isotope signatures, a problem that has not been thoroughly taken into account in crustal evolution models (Payne et al., 2016; Roberts et al., 2012; Roberts and Spencer, 2015). Mafic magmas emplaced shortly after continental collision represent a typical, yet poorly considered case: although of unambiguous mantle origin (Bonin, 2004), they display "crustal" wholerock radiogenic isotopes compositions (Nelson, 1992; Turpin et al., 1988) and zircon Hf isotopic signatures (e.g. Heilimo et al., 2013; Laurent and Zeh, 2015; Liu et al., 2014; Siebel and Chen, 2009; Zhao et al., 2013). Although such mafic magmas are ubiquitous amongst orogenic systems since the late Archean and may be the parent of volumetrically important granite suites (Fowler and Henney, 1996; Laurent et al., 2013), little attention has been paid so far to their role in the formation of new crust, as well as the impact of their ambiguous isotopic signatures on continental evolution models.

This study aims to review the characteristics and petrogenesis of post-collisional mafic magmas; propose a unified model to explain their origin; quantify to what extent they contribute to the formation of new crust; and address the potential biases introduced by their zircon $\mathrm{Hf}-\mathrm{O}$ isotopic signature in global, zirconbased crustal evolution models. We address these issues using: (i) a new, comprehensive geochemical and zircon Hf-O isotopic dataset of post-collisional mafic magmas from the Variscan French Massif Central, and (ii) a global compilation of geochemical data from similar rocks over geological time.

\section{Post-Collisional Mafic Magmas (PCMM)}

\subsection{Geological setting}

Hereafter, the post-collisional period is referred to as the stage of the orogenic cycle immediately following the docking of two continental masses. Voluminous magmatism, often referred to as "syn- to post-collisional" (Bonin, 2004), takes place at that stage. The corresponding volcanic/plutonic rocks belong to two contrasting suites: (i) a peraluminous silicic suite, originating from melting of the local crust; and (ii) a mafic-felsic high-K calc-alkaline association in which the felsic material is generally regarded as the result of differentiation of the mafic parental melt, with varying contributions (assimilation/mixing) from the older crust (Bonin, 2004; Küster and Harms, 1998; Laurent et al., 2013; Liégeois et al., 1998; Moyen et al., in press). In this contribution, we focus on the genesis of the mafic parents of the high-K calc-alkaline suite that will be referred to as Post-Collisional Mafic Magmas (PCMM) hereafter. PCMM have been recognized in most orogenic systems since the late Archean, especially those corresponding to the amalgamation of the main supercontinents in Earth history (Table 1; see also Murphy, 2013). Because of their peculiar characteristics, they are often mentioned using local, non-IUGS nomenclature (Table 1) that hampers a comprehensive view of their global significance.

\subsection{Case study: the Variscan French Massif Central}

The Variscan belt of western Europe (Fig. 1a) was formed during the assembly of Pangea, as a result of the convergence between Laurussia and Gondwana from 420 to 295 Ma. In the eastern French Massif Central (FMC), continental collision took place 

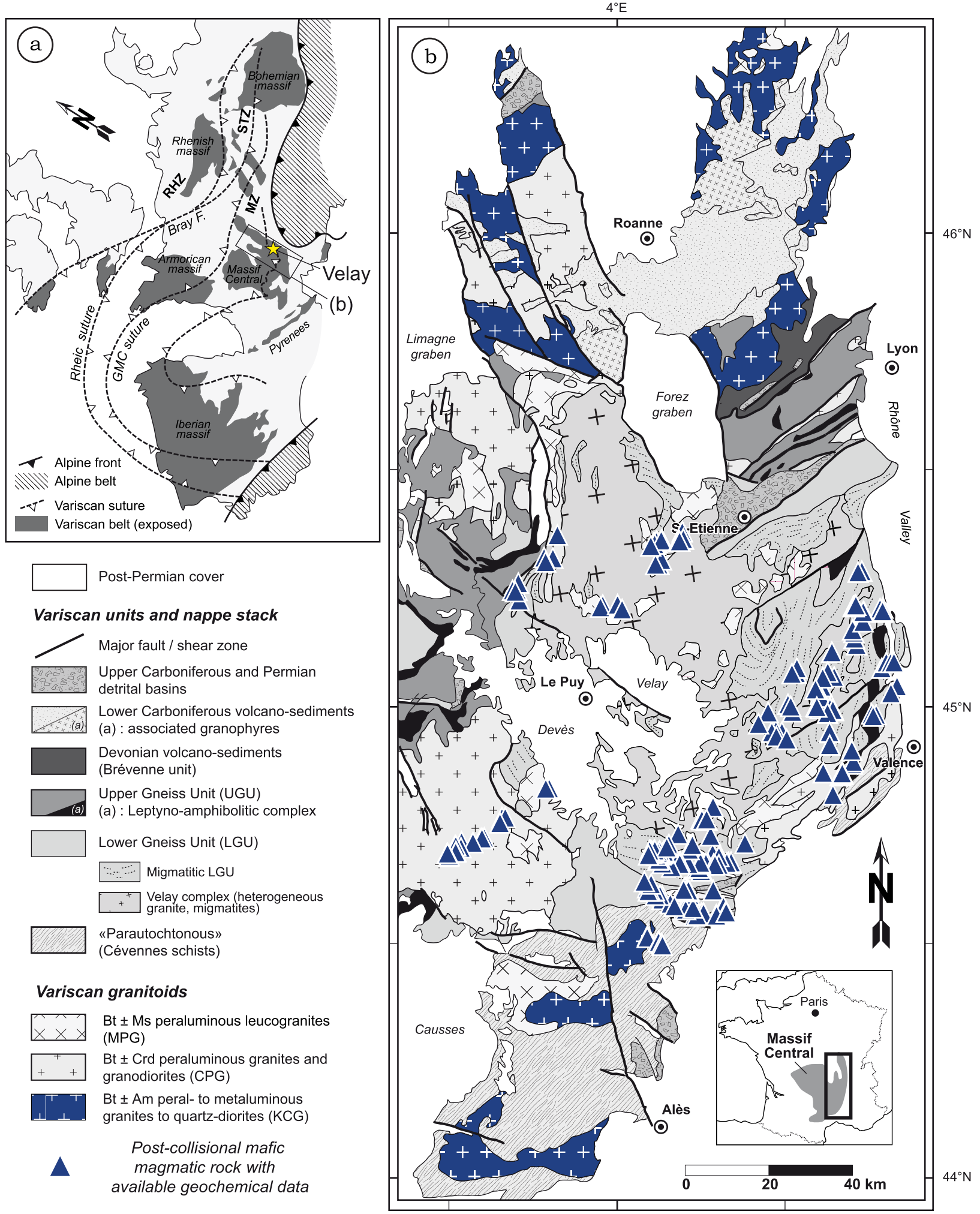

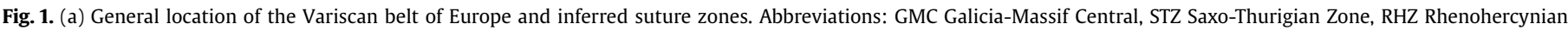

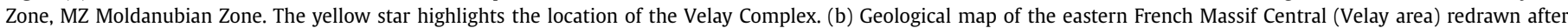

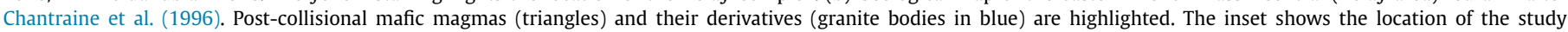
area within the Massif Central. (For interpretation of the references to color in this figure legend, the reader is referred to the web version of this article.)

at c. 360-340 Ma and was followed by orogenic extension and collapse. The latter stage was associated with significant crustal melting resulting in widespread granite magmatism and the formation of granite-migmatite domes (e.g. Velay Complex) (Ledru et al., 2001 and references therein). PCMM are present throughout the Variscan belt (von Raumer et al., 2014). In the eastern FMC, they intruded the crust from c. 335 to 300 Ma (Couzinié et al., 2014; Laurent et al., 2015), forming meter- to hectometer-sized (monzo)diorite to monzonite bodies in granites/migmatites; and dykes at shallower crustal levels (Couzinié et al., 2014). These rocks 
consist of an assemblage of plagioclase, amphibole, biotite and clinopyroxene; with orthopyroxene, K-feldspar and quartz in subordinate and various proportions (Sabatier, 1991). Accessory minerals include apatite, allanite, titanite and zircon. Like in other PCMM occurrences worldwide (e.g. Laurent et al., 2014a; Murphy, 2013), the predominance of biotite and/or amphibole as main mafic minerals points to high $\mathrm{H}_{2} \mathrm{O}$ contents in the original magma. In the FMC, a suite of K-rich calc-alkaline granitoids demonstrably results from differentiation of PCCM with little or no input from the older crust (Moyen et al., in press). In this area, PCMM and their derivatives represent $\approx 10 \%$ of the exposed surface (Moyen et al., in press).

\subsection{Samples, methods and data compilation}

In this study, we present new whole-rock geochemical data and a new zircon Lu-Hf and $\mathrm{O}$ isotope dataset on PCMM from the eastern FMC (Fig. 1b). The whole-rock major and trace element compositions of 27 samples are reported in the Supplementary Material (Table S1). The Hf isotopic composition of zircons from 12 samples was measured by laser ablation - multicollector - inductively coupled plasma - mass spectrometry (LA-MC-ICP-MS) at Goethe Universität Frankfurt, Germany, after imaging of internal zircon structures (cathodoluminescence and back-scattered electron images) by scanning electron microscopy. The zircons were previously analyzed for $\mathrm{U}-\mathrm{Pb}$ isotopes by LA-ICP-MS for age determination (Laurent et al., 2015). Out of the 12 samples investigated for $\mathrm{Hf}$ isotopes, zircons from 8 samples were also analyzed for $\mathrm{O}$ isotopes by SHRIMP at the University of Granada, Spain. The nature and ages of the investigated samples are detailed in Table 2; the Supplementary Material contains details about analytical methods, results of standard measurements (Table S2 for Hf and S4 for O) and the complete datasets (Table S3 for Hf, Table S5 for O).

We also present a compilation of data from PCMM worldwide, available in the Supplementary Materials and including whole-rock geochemistry $\left(N_{\text {samples }}=1647\right.$; Table S6) and zircon Hf $\left(N_{\text {spots }}=2425\right.$; Table S7) and O $\left(N_{\text {spots }}=633\right.$; Table S8) isotopes.

\section{Whole-rock geochemistry and Hf-O isotope composition of PCMM}

\subsection{Whole-rock geochemistry}

PCMM all share similar geochemical features (Fig. 2). They are mafic to intermediate (44 to $63 \mathrm{wt} . \% \mathrm{SiO}_{2}$ ) and dominantly plot in the high-K calc-alkaline to shoshonite fields (Fig. 2a). PCMM typically show a dual geochemical signature characterized by richness in both compatible and incompatible elements (Fowler and Rollinson, 2012; Holub, 1997; Laurent et al., 2014b). In PCMM from the FMC, this is best illustrated by high contents in both $\mathrm{K}_{2} \mathrm{O}$ (1.0-7.5 wt.\%) and $\mathrm{FeO}_{\mathrm{t}}+\mathrm{MgO}$ (7-25 wt.\%) (Fig. 2b). Likewise, both $\mathrm{Ba}+\mathrm{Sr}(0.1-0.6$ wt.\%) and $\mathrm{Ni}+\mathrm{Cr}$ contents (50-1000 ppm) are very high (Fig. 2c). Notably, there is no correlation whatsoever between compatible and incompatible elements (Fig. 2b, c). PCMM display high LREE and HFSE contents (Fig. 2d), together with crustlike incompatible trace element patterns systematically characterized by negative $\mathrm{Nb}-\mathrm{Ta}$ and $\mathrm{Ti}$ anomalies (Fig. 2e). Strikingly, these rocks are markedly enriched in most incompatible elements (LILE, LREE, HFSE) relative to the bulk continental crust (Fig. 2e).

\subsection{Hf isotopes}

A compilation of available zircon $\mathrm{Hf}$ isotopic data from PCMM in various orogenic systems is presented in Fig. 3a. Apart from a few exceptions, such zircons display (sub-)chondritic $\varepsilon \mathrm{Hf}_{(\mathrm{t})}$, clearly

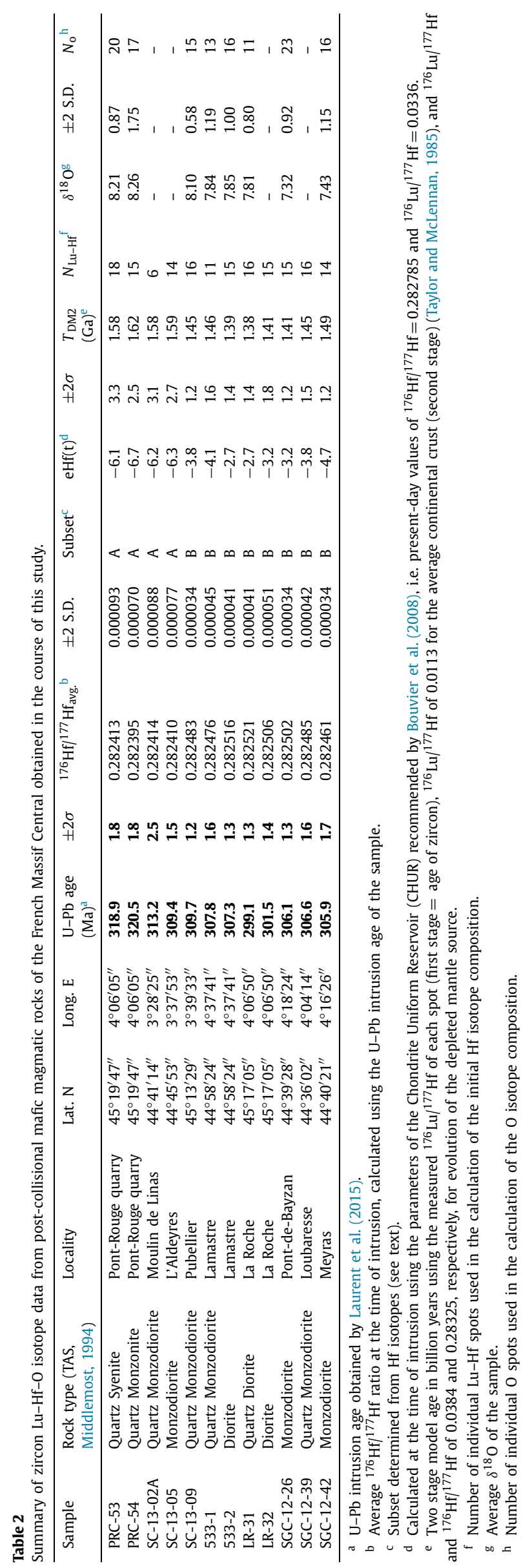



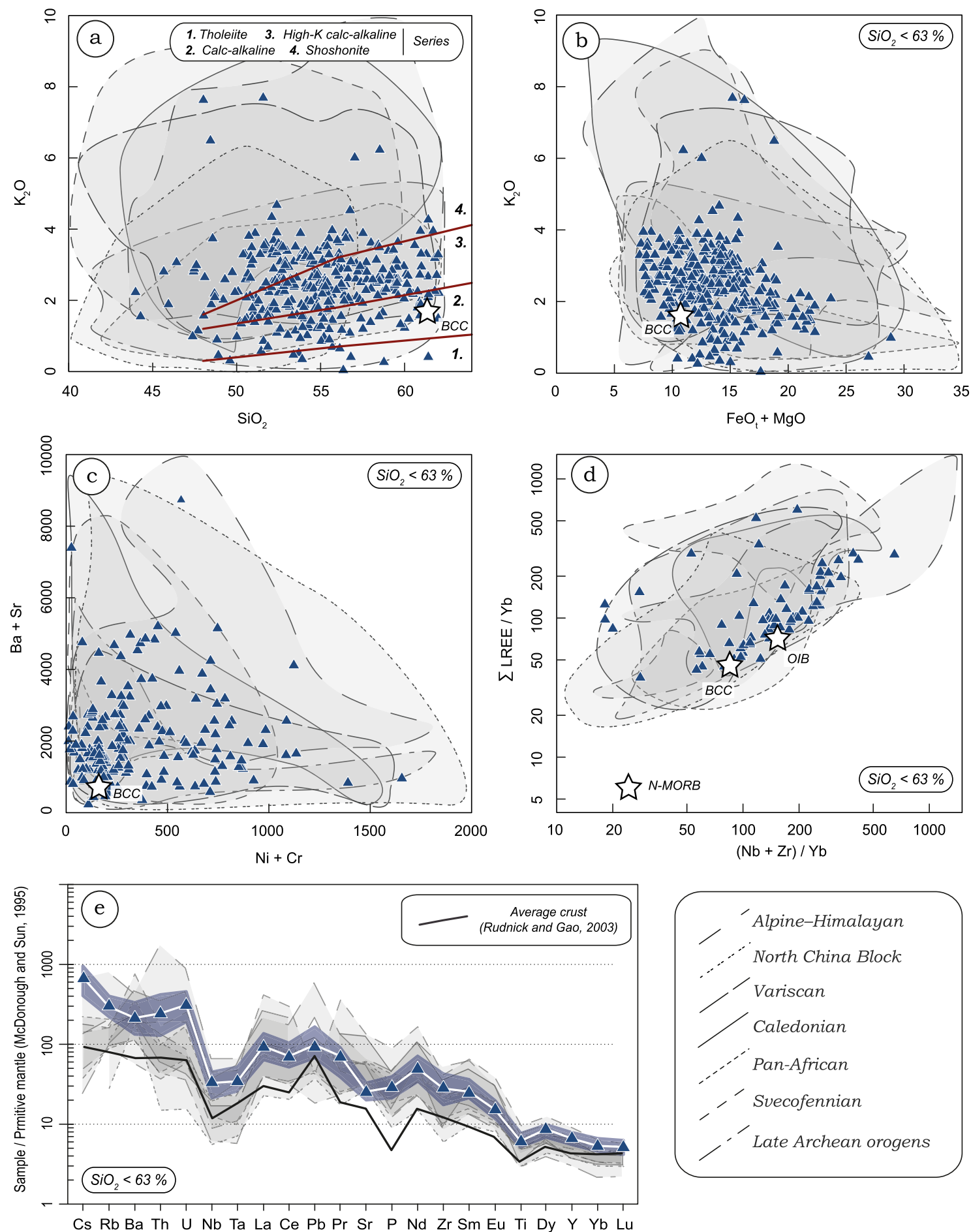

Cs Rb Ba Th U Nb Ta La Ce Pb Pr Sr P Nd Zr Sm Eu Ti Dy Y Yb Lu

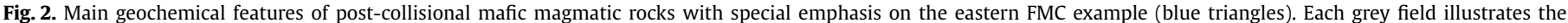

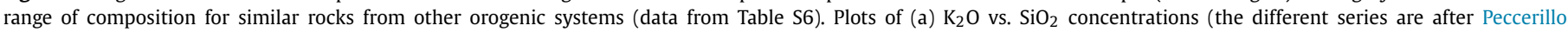

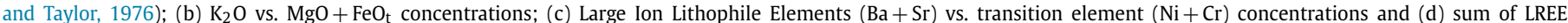

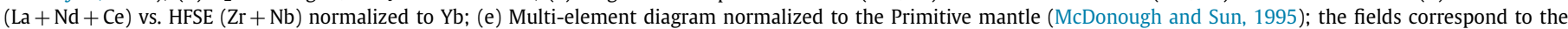

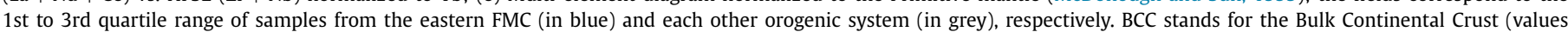

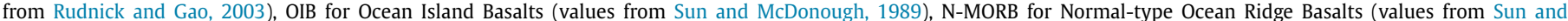
McDonough, 1989). (For interpretation of the references to color in this figure legend, the reader is referred to the web version of this article.)

differing from that of DM at the time of magma formation. This typical feature of PCMM is well reflected by rocks from the eastern FMC (Fig. 3b and Table 2). Zircon grains from such rocks show simple internal structures, without core-rim relationships and yield a single population of concordant U-Pb ages (Couzinié et al., 2014; Laurent et al., 2015). This argues for a single event of zircon forma- tion during magma crystallization and limited or no host-rock assimilation. Hence, the initial Hf isotopic composition $\left({ }^{176} \mathrm{Hf} /{ }^{177} \mathrm{Hf}_{\mathrm{t}}\right)$, can reliably be considered as representative of that of the magma at the time of zircon crystallization.

The newly-obtained zircon Hf dataset for PCMM from the FMC can be divided into two subsets (Table 1). Subset A comprises 

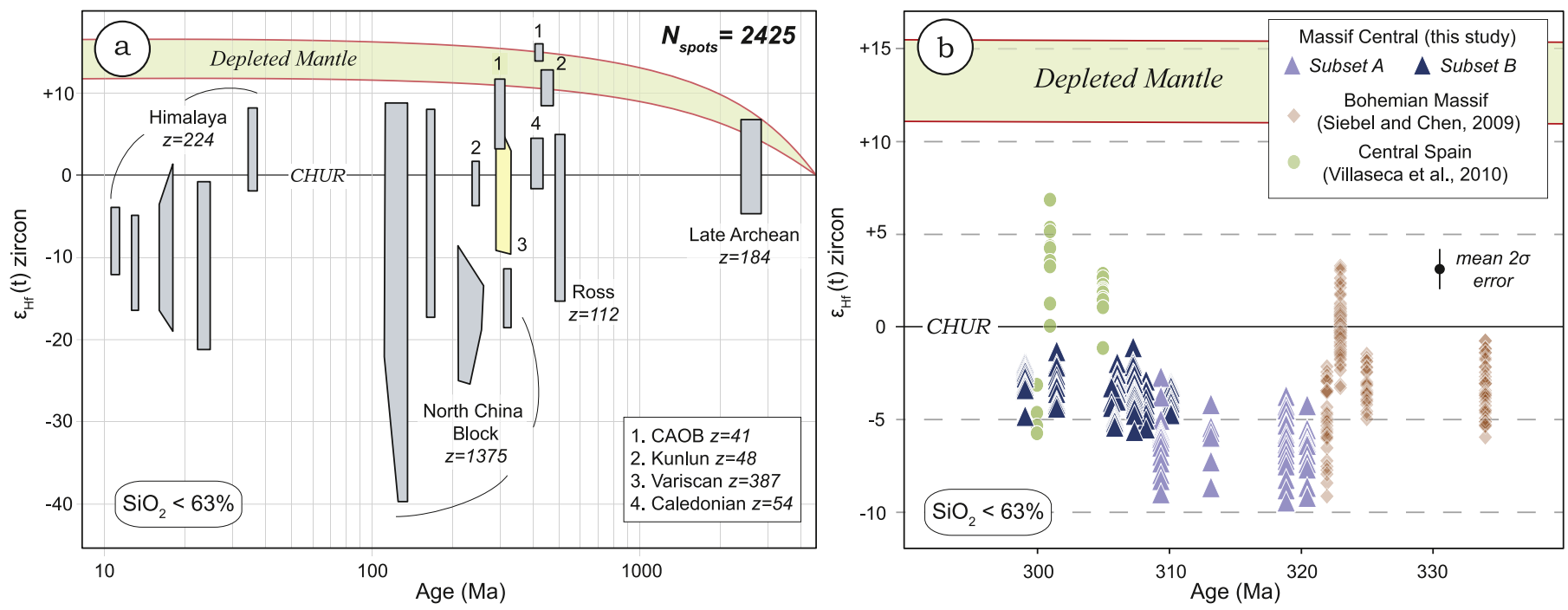

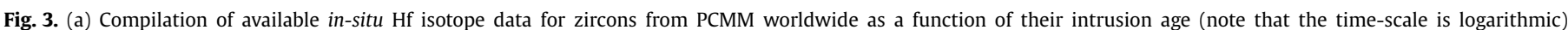

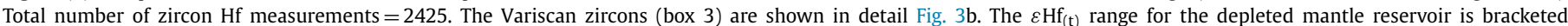

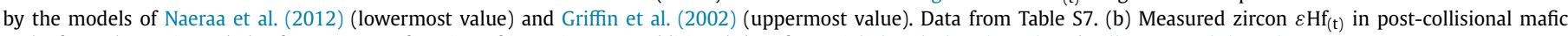
rocks from the Variscan belt of Europe as a function of intrusion age. Additional data from Siebel and Chen (2009) and Villaseca et al. (2010).

the four oldest samples of the investigated dataset (309-320 Ma). The zircon ${ }^{176} \mathrm{Hf} /{ }^{177} \mathrm{Hf}_{\mathrm{t}}$ ratios of samples from subset A range from $0.282319 \pm 0.000032$ to $0.282480 \pm 0.000028$ (2 S.E. - standard error), corresponding to subchondritic $\varepsilon \mathrm{Hf}_{(\mathrm{t})}$ of -3.7 to -9.4 (Fig. 3b). Subset B includes the younger samples, all having ages in the range 299-310 Ma. Their zircons have ${ }^{176} \mathrm{Hf} /{ }^{177} \mathrm{Hf}_{\mathrm{t}}$ ranging between $0.282441 \pm 0.000026$ and $0.282562 \pm 0.000026$ (2 S.E.) corresponding to subchondritic $\varepsilon \mathrm{Hf}_{\mathrm{t}}$ of -1.1 to -5.0 (Fig. $3 b$ ). The $\varepsilon \mathrm{Hf}_{\mathrm{t}}$ variability within a given sample is small (always $<3 \varepsilon$ Hf-units) and in most cases close to the analytical uncertainties (i.e. $\pm 1.1 \varepsilon$ Hf-units), indicating that zircons crystallized from a magma with homogeneous Hf isotope composition. Although some overlap occurs between the two groups, zircons from samples of subset A have more variable (the scatter is always $>4 \varepsilon$ Hf-units for a given sample) and generally less radiogenic ${ }^{176} \mathrm{Hf} /{ }^{177} \mathrm{Hf}_{\mathrm{t}}$ than samples from subset $\mathrm{B}$, with most grains having $\varepsilon \mathrm{Hf}_{\mathrm{t}}$ lower than -5 and down to -9.4 (Fig. $3 \mathrm{~b}$ ). Because of this large dispersion, the average $\varepsilon \mathrm{Hf}_{\mathrm{t}}$ calculated for each sample of subset A is probably of little geological significance and the scatter may rather correspond to heterogeneous Hf isotope composition of the original magma.

\subsection{Oxygen isotopes}

Fig. 4a summarizes available in situ $\mathrm{O}$ isotopes measurements on PCMM zircons. The $\delta^{18} \mathrm{O}_{\text {SMOw }}$ of zircons from PCMM are highly variable and range from +2.5 to $+10 \%$. They are often out of the range of $\delta^{18} \mathrm{O}_{\mathrm{SMOW}}$ expected for zircons crystallizing from mantle-derived magmas, especially in the most recent (Himalayan, Variscan and Caledonian) orogens (Fig. 4a).

All zircon data from PCMM of the eastern FMC show high $\delta^{18} \mathrm{O}_{\text {SMOW }}$ values (Fig. 4b), mostly between $6.39 \pm 0.32$ and $8.92 \pm$ $0.26 \%$ (2 S.E. - standard error) with a few spots with even higher $\delta^{18} \mathrm{O}_{\text {SMOW }}$ up to $9.97 \pm 0.24$. The variability per sample is typically large, $>0.6 \%$ ( 2 S.D.), i.e. well above the range of analytical uncertainties $(<0.3 \%$; see Table S5). This argues for heterogeneous $\mathrm{O}$ isotope compositions of the magmas at the time of zircon crystallization.

\section{Discussion}

\subsection{Petrogenesis of PCMM in the FMC}

\subsubsection{Source vs. emplacement processes}

The most mafic components of the PCMM suite in the FMC display low $\mathrm{SiO}_{2}(<53 \%)$, with high $\mathrm{MgO}+\mathrm{FeO}_{\mathrm{t}}(>12 \%)$ and transition element $(\mathrm{Cr}>250 \mathrm{ppm}$. Ni $>120 \mathrm{ppm})$ contents. This demonstrates that the parental melt cannot be derived from crustal lithologies, but rather equilibrated with a(n) (ultra)mafic residue (i.e. peridotite/pyroxenite) (Holub, 1997; Sabatier, 1991). From that perspective, the high incompatible element contents and "crustlike" Hf-O isotopic signatures of PCMM could result from two distinct processes: (i) evolution of an incompatible element-poor, mantle-derived basaltic melt by fractionation and/or assimilation of crustal lithologies (i.e. AFC processes); or (ii) partial melting of a mantle source already enriched in $\mathrm{K}_{2} \mathrm{O}, \mathrm{H}_{2} \mathrm{O}$ and LILE.

Several lines of evidence indicate that AFC cannot explain the geochemical signature of PCMM:

(1) Even starting from an "enriched" basaltic composition (i.e. OIB-like), considerable amounts of crystallization (>50\%) are required to drive the incompatible element contents to the elevated concentrations observed in PCMM, such that the final melt would certainly not be mafic any more (Fig. 5a).

(2) Assimilation of continental crust during magma emplacement is precluded by the lower incompatible element contents of the most widespread crustal lithologies compared with PCMM, which holds true for both the FMC case and the global perspective (inset Fig. 5a).

(3) Even assuming that a crustal contaminant with the adequate trace element composition exists in the FMC and that only limited fractionation $(\leq 20 \%)$ took place so that the final magma remained mafic, AFC calculations show that driving the $\mathrm{Hf}$ isotopic composition of a DM-derived basalt to that of the PCMM would require a crustal contaminant with $\varepsilon \mathrm{Hf}_{310 \mathrm{Ma}}$ of -50 (Fig. 6a), corresponding to an early Archean crustal component (model age $>3.6 \mathrm{Ga}$ ). This is extremely unlikely in the case of the FMC where the oldest crust is early Paleozoic to Neoproterozoic in age (Melleton et al., 2010). 

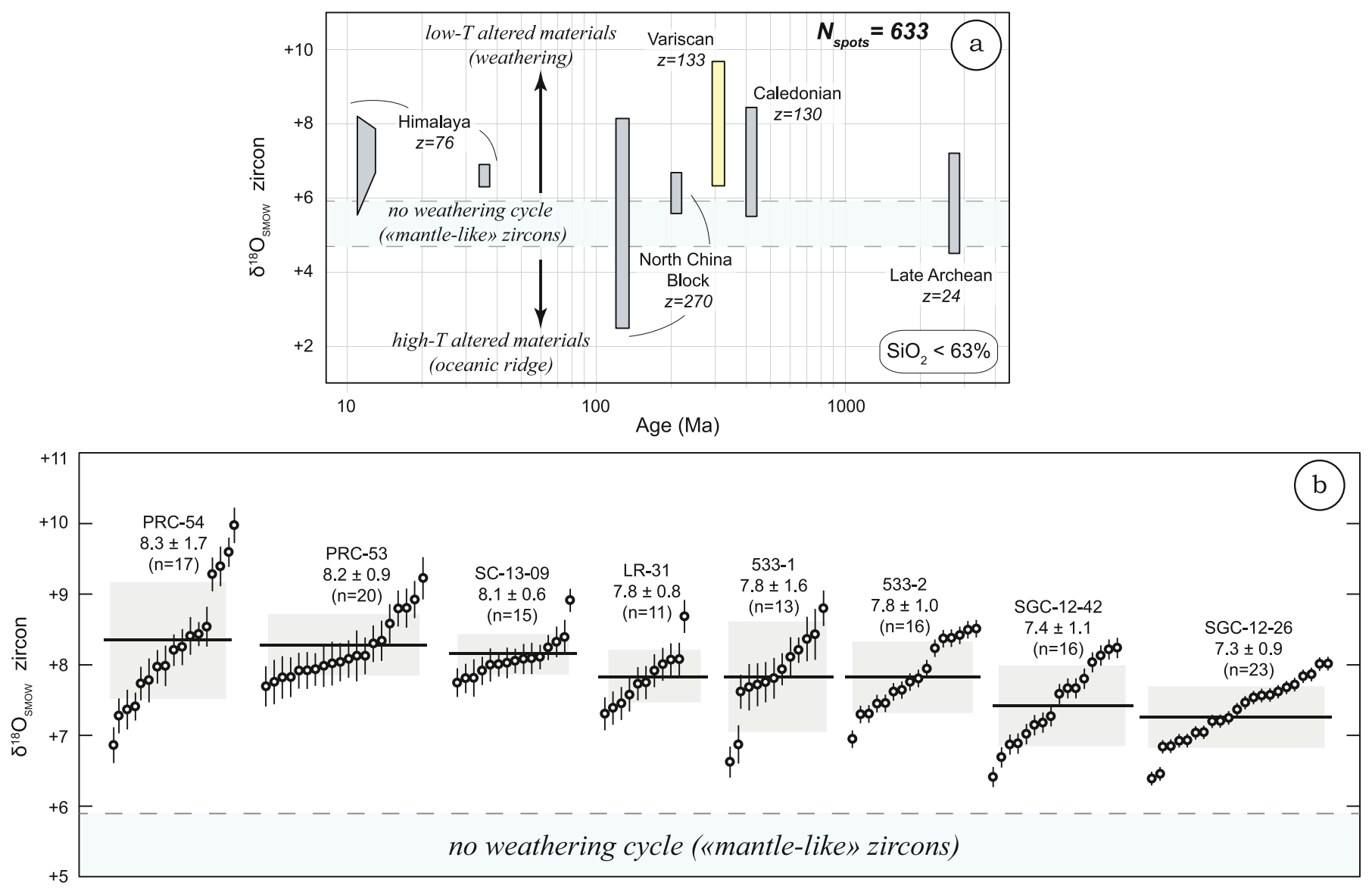

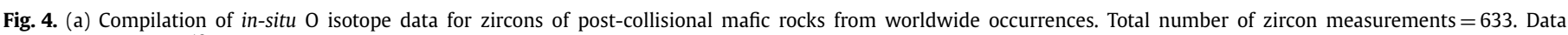

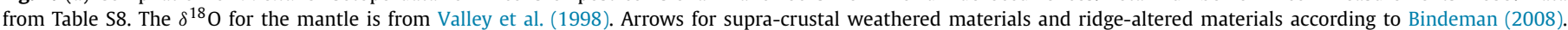

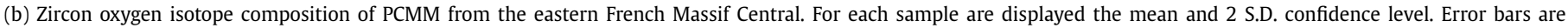
the analytical standard errors of each measurement plotted at $2 \sigma$.

In contrast, $\mathrm{PCMM}$ plausibly represent primary melts derived from an anomalously $\mathrm{K}_{2} \mathrm{O}$-, LILE- and $\mathrm{H}_{2} \mathrm{O}$-rich mantle. Indeed, experimental melting of phlogopite- and/or amphibole-bearing (i.e. K-rich) peridotites, particularly spinel-lherzolites, yields melts with major element compositions matching those of PCMM from the FMC (Fig. 5b) (Conceição and Green, 2004; Condamine and Médard, 2014; Green, 2015; Mengel and Green, 1989; Thibault et al., 1992). Importantly, experiments conducted with mixed peridotite + felsic (granitoid) starting materials produce melts of similar compositions (Mallik et al., 2015; Prouteau et al., 2001; Rapp et al., 2010). The two sets of experiments are equivalent from a petro-geochemical point of view because, in the second approach, the mixture yields a phlogopite- and/or amphibole-bearing peridotite/pyroxenite in equilibrium with a mafic K-rich melt. Therefore, experimental evidence unequivocally shows that hybridization between peridotite and a felsic component is required to explain the major-element composition of PCMM (irrespective of the hybridization mechanism and the exact nature of the felsic component, which are discussed in \$4.1.2).

The same conclusion can be drawn for trace elements. We calculated the REE contents of a melt generated from a hybrid source consisting of $75-90 \%$ DM and $10-25 \%$ of a LREE-rich component (having the composition of the bulk continental crust). Fig. $5 \mathrm{c}$ shows that the resulting melts (for 5 to $20 \%$ melting) match the composition of PCMM from the FMC, again with a better fit for a spinel-facies source.

Therefore, we propose that PCMM in the FMC result from partial melting, at $<2 \mathrm{GPa}$, of a phlogopite-/amphibole-bearing peri- dotite (or pyroxenite) corresponding to mantle domains enriched in $\mathrm{K}_{2} \mathrm{O}, \mathrm{H}_{2} \mathrm{O}$ and other incompatible elements.

\subsubsection{Mechanism of mantle enrichment and nature of the metasomatic agent}

Considering that they reflect the composition of the hybrid mantle source, the observed negative $\varepsilon \mathrm{Hf}_{\mathrm{t}}$ signatures in PCMM zircons can be explained by two distinct scenarios: (i) contamination of the mantle (with $\varepsilon \mathrm{Hf}_{\mathrm{t}}>>0$ ) by crustal material with strongly negative $\mathrm{Hf}$ isotope composition $\left(\varepsilon \mathrm{Hf}_{\mathrm{t}}<<0\right)$ shortly prior to PCMM formation; or (ii) a long time span between mantle contamination (by any material having low ${ }^{176} \mathrm{Lu} /{ }^{177} \mathrm{Hf}$ ) and PCMM formation, whereby the initial decrease of the mantle ${ }^{176} \mathrm{Lu} /{ }^{177} \mathrm{Hf}$ ratio leads to a time-integrated, non-radiogenic Hf isotope composition.

Several lines of evidence clearly favor the first hypothesis. Firstly, the mantle beneath the FMC (sampled as xenoliths in Cenozoic volcanoes) do not show evidence for any geological event older than ca. 0.6 Ga (Wittig et al., 2007), which is also the age of the oldest autochtonous crust (Melleton et al., 2010). In contrast, the strongly negative $\varepsilon \mathrm{Hf}_{\mathrm{t}}$ of PCMM zircons in the FMC would require the involvement of much older mantle, of at least Mesoproterozoic age ( $>1.1 \mathrm{Ga}$, considering an unlikely ${ }^{176} \mathrm{Lu} /{ }^{177} \mathrm{Hf}=0$ for the source). Secondly, prior to the emplacement of PCMM in the late Carboniferous (330-300 Ma), other mafic magmas were emplaced throughout the FMC during the late Devonian and early Carboniferous (380-360 Ma) and contrastingly show positive bulk-rock $\varepsilon \mathrm{Nd}_{\mathrm{t}}$ ( +1 to +5 , up to +8 ) (Pin and $\mathrm{Pa}$ quette, 1997, 2002), indicative of a depleted mantle origin. If any long-term enriched mantle could have survived underneath the 
FMC, it is difficult to envisage that it would have been sampled by magmatism at ca. 330-300 Ma, but not at 380-360 Ma, especially since "enriched" upper mantle domains are particularly prone to melting (solidus temperatures as low as $1025-1075^{\circ} \mathrm{C}$ at $1 \mathrm{GPa}$; Conceição and Green, 2004; Condamine and Médard, 2014). Thirdly, PCMM of the FMC only post-date by $50-100 \mathrm{Ma}$ an episode of Silurian-Devonian tectonic accretion and subduction of continental/oceanic units belonging to the northern margin of Gondwana (Faure et al., 2008; Melleton et al., 2010). Such units, now exposed as migmatitic ortho- and paragneisses containing eclogitic relics, were buried at depths $>100 \mathrm{~km}$ and underwent HP partial melting (Faure et al., 2008; Lardeaux et al., 2001;
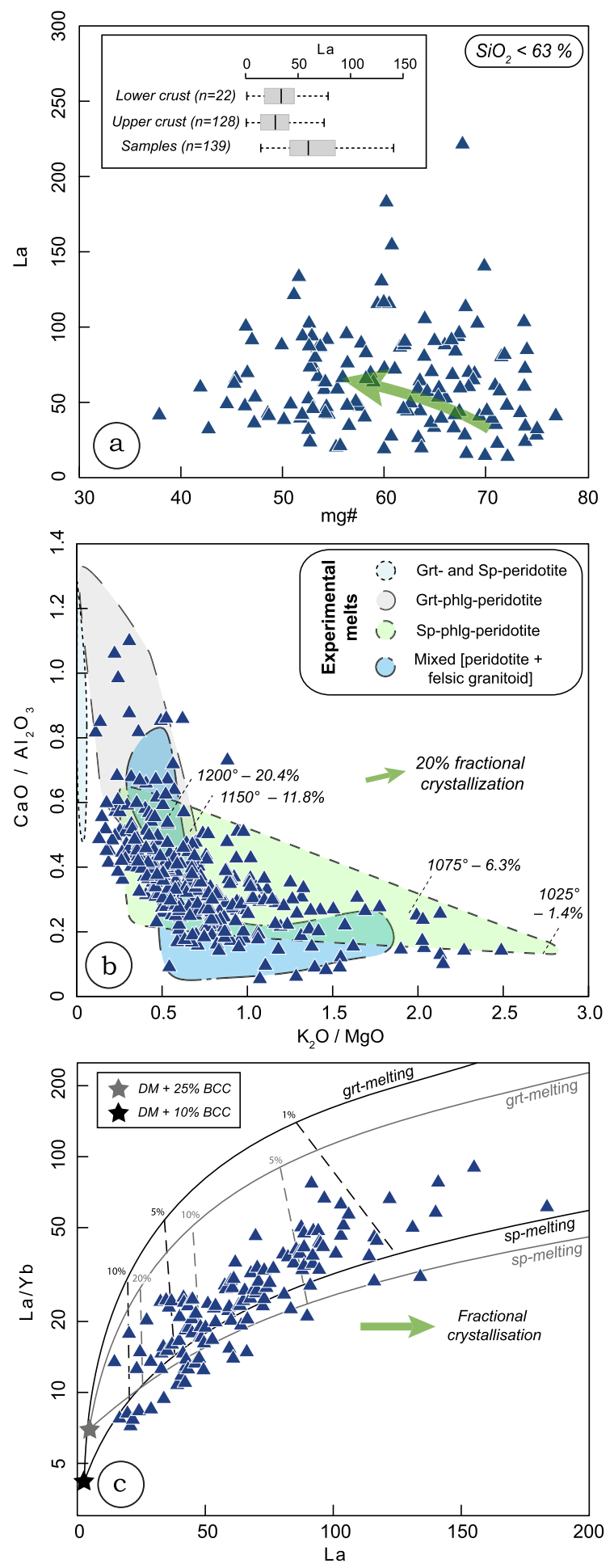

Pin and Lancelot, 1982), thereby providing a straightforward way to metasomatize the mantle with crustal-derived $\mathrm{K}-, \mathrm{H}_{2} \mathrm{O}$ - and LILE-rich material. The same model was proposed to explain the occurrence of PCMM in the Variscan Bohemian Massif (Janoušek and Holub, 2007), the Himalayas (Campbell et al., 2014; Guo et al., 2014) and the Dabie-Sulu orogen (Zhao et al., 2013).

Importantly, mass balance calculations show that binary mixing between (i) $80-90 \% \mathrm{DM}$ and (ii) $10-20 \%$ of a crustal component with $\varepsilon \mathrm{Hf}_{\mathrm{t}}=-10$ and $\delta^{18} \mathrm{O}=+20 \%$ readily explains the $\mathrm{Hf}-\mathrm{O}$ isotopic composition of PCMM zircons in the FMC (Fig. 6b). High $\delta^{18} \mathrm{O}$ is typically observed in subducted continental sedimentary materials having experienced a low- $T$ weathering cycle, e.g. the East Indonesian $\left(\delta^{18} \mathrm{O}=+15\right.$ to +24 ; Vroon et al., 2001) or Lesser Antilles $\left(\delta^{18} \mathrm{O}=+19\right.$ to +21 ; Davidson, 1987) sediments. Moreover, the pre-Variscan crust of the FMC is dominated by paragneisses (and meta-granitoids derived from melting of the latter) corresponding to former sediments of the north Gondwana margin, which are characterized by Archean (2.5-3.3 Ga), Paleoproterozoic (1.8-2.2 Ga) and Neoproterozoic (0.5-0.7 Ga) detritus, as indicated by age patterns of detrital zircon grains (Albert et al., 2015; Linnemann et al., 2014). Fig. 7a shows that a mixture of these three crustal components, including at least $45-85 \%$ of Paleoproterozoic-Archean crust, would readily account for the inferred $\mathrm{Hf}$ isotopic signature $\left(\varepsilon \mathrm{Hf}_{310 \mathrm{Ma}}=-10 ; T_{\mathrm{DM}}=1.8 \mathrm{Ga}\right)$ of the crustal material in the hybrid mantle source. In fact, the bulk Hf budget carried by detrital zircons in the pre-Variscan crust of the FMC is consistently characterized by an average $\varepsilon \mathrm{Hf}_{310 \mathrm{Ma}}$ of ca. -10 (Fig. 7b). This observation clearly supports that the hybrid source of PCMM in the FMC results from interactions between mantle peridotite and subducted pre-Variscan continental shelf sediments of the former north Gondwana margin.

Further constraints on the nature of the crust-derived materials and how they were incorporated in the mantle can be placed by considering bulk rock Th/La ratios, which are not significantly fractionated during mantle melting (Plank, 2005). Indeed, the source of PCMM samples with the highest Th/La and $\delta^{18} \mathrm{O}$ and lowest $\varepsilon \mathrm{Hf}_{\mathrm{t}}$ (Subset A) was likely metasomatized by felsic melts derived

Fig. 5. Plots of major and trace element characteristics of PCMM from the eastern French Massif Central (only samples with $\mathrm{SiO}_{2}<63 \%$ ) highlighting important features of their petrogenesis. (a) Plot of La concentrations vs. Mg\# $\left(100^{*} \mathrm{MgO} /\left(\mathrm{FeO}_{\mathrm{t}}+\mathrm{MgO}\right)[\mathrm{mol}]\right)$ showing no particular correlation, precluding any significant role played by fractionation or crustal assimilation/contamination. The green arrow shows the evolution of a primary melt $(\mathrm{La}=37 \mathrm{ppm}$, similar to OIB, Sun and McDonough (1989); $M g \#=70$ ) for $50 \%$ fractional crystallization of a $25 \%$ clinopyroxene $+10 \%$ plagioclase $+60 \%$ biotite $+5 \%$ olivine assemblage $(\mathrm{Mg} \#=77)$, supposedly controlling the liquid line of descent of PCMM (mineral proportions and compositions from Parat et al., 2009). Partition coefficients are from Lee et al (2007) for olivine and clinopyroxene, from Grégoire et al. (2000) for phlogopite, from McKenzie and O'Nions (1991) for garnet and plagioclase. Inset: La contents of FMC samples compared with those of the local upper (Moyen et al., in press) and lower (Downes et al., 1990) crust. (b) Major element ratios of PCMM and comparison with experimental liquids obtained by (i) melting of metasomatized, phlogopite- and/or amphibole-bearing peridotites (Conceição and Green, 2004; Condamine and Médard, 2014; Green, 2015; Mengel and Green, 1989; Thibault et al., 1992); (ii) melting of phlogopite-free peridotites (Gaetani and Grove, 1998; Tenner et al., 2012); and (iii) mixed peridotite + felsic granitoid sources (Mallik et al. 2015; Prouteau et al., 2001; Rapp et al., 2010). The temperatures (in ${ }^{\circ} \mathrm{C}$ ) and melt fractions (in \%) indicated in the field of spinel phlogopite peridotite correspond to the experimental conditions and results of Condamine and Médard (2014). The arrow shows the variation of elemental ratios for $20 \%$ fractional crystallization of the assemblage mentioned above. (c) La/Yb vs. La plot with batch melting models (curves) of spinel and garnet phlogopite peridotite. Source compositions correspond to the Depleted Mantle (Workman and Hart, 2005) mixed with 10\% to 25\% Bulk Continental Crust (Rudnick and Gao, 2003) (black and gray stars, respectively). Partition coefficients for olivine, clinopyroxene and phlogopite as mentioned above, orthopyroxene from Lee et al. (2007). Modal proportions in the residue are recalculated from Condamine and Médard (2014) for spinel peridotite (olivine 0.69 orthopyroxene 0.15 , clinopyroxene 0.08 , phlogopite 0.07 , spinel 0.01 ) and Thibault et al. (1992) for garnet peridotite (olivine 0.25 , orthopyroxene 0.5 , clinopyroxene 0.15 , phlogopite 0.03 , garnet 0.07 ). (For interpretation of the references to color in this figure legend, the reader is referred to the web version of this article.) 
from terrigenous sediments (Fig. 6c, d), which is consistent with the fact that subducted rocks in the FMC underwent melting at HP (Faure et al., 2008; Pin and Lancelot, 1982). The other samples (Subset B) are better explained by mixing between DM and a bulk continental crust composition (Fig. $6 \mathrm{c}, \mathrm{d}$ ), possibly resulting from mechanical mélanges during the subduction of the continental units. Importantly, compositions corresponding to average, bulk lower crust (low Th/La) cannot account for the observed compositions, even if we consider that such material had high $\delta^{18} \mathrm{O}$ and low $\varepsilon \mathrm{Hf}_{\mathrm{t}}$ (Fig. 6c, d), showing that subduction of supracrustal material is required.
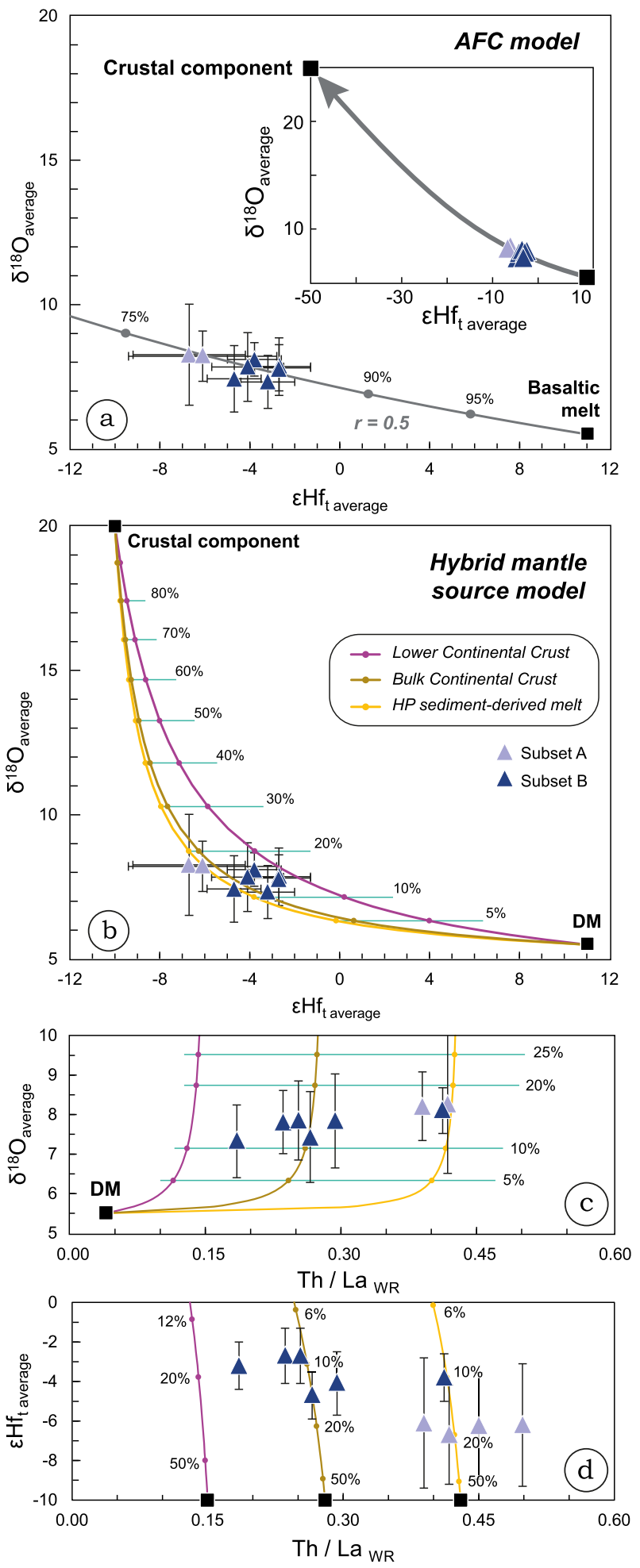

\subsection{A unified model for PCMM petrogenesis}

As outlined earlier, PCMM worldwide share a common geotectonic, petrographic identity and similar geochemical and $\mathrm{Hf}-\mathrm{O}$ isotopic characteristics, which argues for a common origin. The fact that our samples from the FMC are chemically representative of the diversity of PCMM worldwide (Fig. 3) suggests that the general features of the petrogenetic model proposed above can be reasonably extended to all PCMM suites.

Consistently, many workers advocated that the particular geochemistry of PCMM necessarily requires an enriched mantle source (Fowler and Rollinson, 2012; Guo et al., 2014; Laurent et al., 2011; Laurent et al., 2014a; Laurent et al., 2014b; Liégeois et al., 1998; Murphy, 2013; Prelevic et al., 2012; von Raumer et al., 2014; Williams et al., 2004). Moreover, the presence of continental crustderived material in such a source has often been proposed to explain the non-DM and "crustal" isotopic signatures of these rocks (Guo et al., 2014; Laurent et al., 2014b; Nelson, 1992; Prelevic et al., 2012). Given the generally higher $\delta^{18} \mathrm{O}$ of PCMM zircons compared with mantle material (Fig. 4a), it is likely that these crustal materials are most often represented by supracrustal rocks. Finally, mantle enrichment shortly prior to PCMM genesis seems to be the rule because, like in the FMC, PCMM emplacement systematically post-dates by $<50 \mathrm{Ma}$ an oceanic and/or continental subduction stage, for instance in the late Archean terranes (Laurent et al., 2014a) and in the Himalayan (Chung et al., 2005), Caledonian (Atherton and Ghani, 2002) and Svecofennian (Andersson et al., 2006) orogens.

Therefore, we propose that PCMM are derived from: (i) interactions between subducted continental material (most often of supracrustal origin), or melts/fluids generated from them, and mantle peridotite; and (ii) subsequent melting of the resulting hybrid source shortly thereafter. Mantle enrichment through the subduction of continental units at the onset of collision (Campbell et al., 2014; Guo et al., 2014; Janoušek and Holub, 2007; Zhao et al., 2013) would be the most appropriate scenario to account for the short time lapse between the two steps; the systematic occurrence of PCMM in collision belts; and the more evolved isotopic composition and greater incompatible element contents of PCMM compared with classical arc magmas (related to oceanic subduction).

\subsection{Quantifying crust and mantle contributions in post-collisional mafic magmas}

The aim of this section is to quantify the respective mass fraction of mantle- vs. crust-derived elements in the "hybrid" mantle source of PCMM. This will be used in turn to determine the mass

Fig. 6. (a) Results of assimilation/fractional crystallization (AFC) model of a basaltic melt (Hf content of 2.03 ppm, from Sun and McDonough, 1989; DM-like isotopic composition with $\varepsilon \mathrm{Hf}_{(\mathrm{t})}=+11$ calculated from Naeraa et al., 2012, and $\delta^{18} \mathrm{O}=+5.3$ from Valley et al., 1998) assimilating bulk continental crust (Hf content of $3.7 \mathrm{ppm}$, from Rudnick and Gao (2003); $\varepsilon \mathrm{Hf}_{(\mathrm{t})}=-50$ and $\delta^{18} \mathrm{O}=+25$ adjusted to fit the data for a maximum fractionation rate of ca. 20\%); grey dots indicate the fraction of remaining liquid and $r$ the mass ratio between assimilated and crystallized material. (b), (c) and (d) Results of mass-balance, binary mixing models between DM $\left(\varepsilon \mathrm{Hf}_{(\mathrm{t})}=+11 ; \delta^{18} \mathrm{O}=+5.3\right.$; Hf contents $[0.2 \mathrm{ppm}]$ and Th/La [0.04] from Workman and Hart (2005)) and three different crustal materials, all characterized by $\varepsilon \mathrm{Hf}_{(\mathrm{t})}=$ -10 and $\delta^{18} \mathrm{O}=+20$ (adjusted to fit the data for a maximum mantle contamination rate of ca. 20\%): (i) a melt derived from HP melting of terrigenous sediment (Hf contents [4.3 ppm] and Th/La [0.43] from Plank and Langmuir, 1998, corrected from HP melting using average partition coefficients of Hermann and Rubatto (2009)); (ii) Lower and (iii) Bulk Continental Crust (Rudnick and Gao, 2003). O contents are from Roberts et al. (2012). Light blue lines denote the percentage of crustal component in the mixture. Errors bars for samples are 2 S.D. All $\varepsilon \mathrm{Hf}_{\mathrm{t}}$ are calculated at $310 \mathrm{Ma}$ (average age of PCMM in the eastern FMC). (For interpretation of the references to color in this figure legend, the reader is referred to the web version of this article.) 

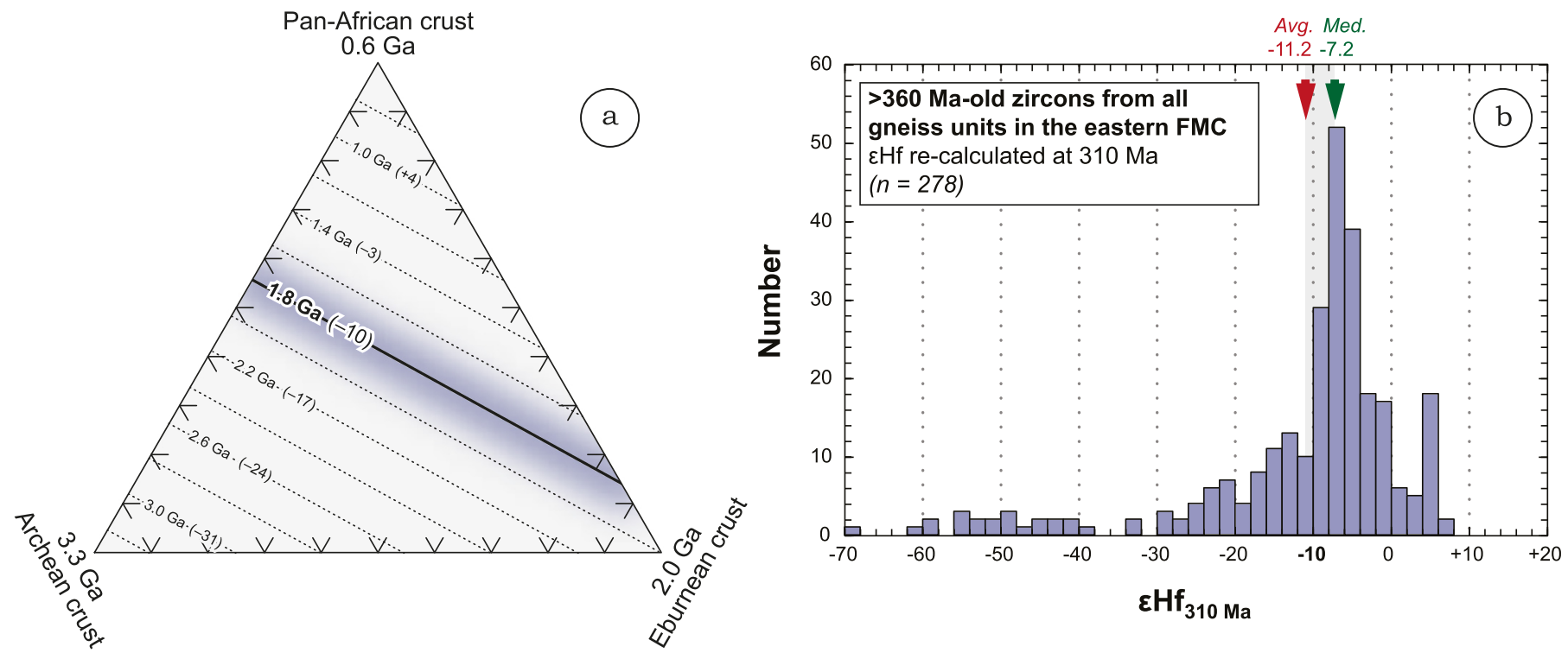

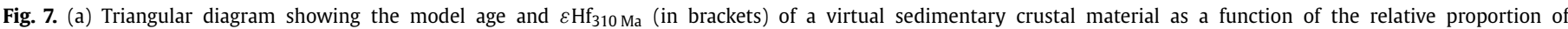

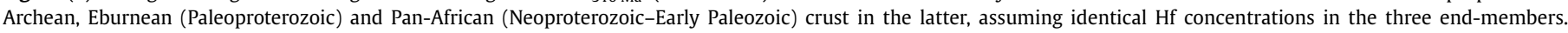

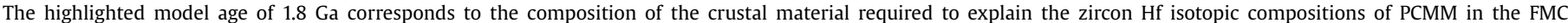

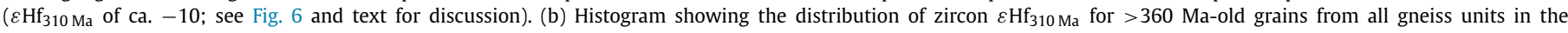

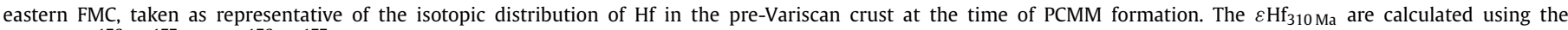
measured ${ }^{176} \mathrm{Hf} /{ }^{177} \mathrm{Hf}$ and ${ }^{176} \mathrm{Lu} /{ }^{177} \mathrm{Hf}$ ratios of each zircon grain. Data from Chelle-Michou et al. (2015).

fraction of PCMM that derives from the mantle, which is a critical parameter to unravel their contribution to crustal growth.

As demonstrated above, the hybrid mantle source of PCMM is formed by interactions between mantle peridotite and crustal materials (fluid, melt or solid). These interactions may result in different cases in nature, e.g. a mechanical mixture of peridotite and meta-sedimentary/meta-igneous crustal rocks; a peridotite containing veins formed by reaction with percolating liquids; or a metasomatized rock where the added material is distributed in newly-crystallized phases (pyroxenes, amphibole, phlogopite). Irrespective of the nature of the metasomatic agent, the finite mass of each chemical element within any of these "hybrid" sources will be partitioned between the fraction that was already present in the original mantle prior to the interactions and that supplied by the added crust-derived material. The dual geochemistry of PCMM shows that they sampled both groups of elements, regardless the exact physical nature of the source and melting process. Therefore, for each chemical element, the mass fraction of "crust" vs. "mantle" atoms in the source of PCMM can be approximated using a simple binary mixing model based on mass-balance, assuming reasonable compositions for the two components (respectively Bulk Continental Crust and DM). Although simplistic, this calculation has the advantage of relying on few parameters, i.e. the mass fractions of the two end-members and their compositions, which in the case of crust-mantle mixing are not so critical given the huge concentration contrast between the two for most elements.

For each chemical element, we define $x_{\text {crust }}$ as the mass fraction of atoms that originates from crust-derived materials. Fig. 8 shows that in a hybrid mantle containing 10 to $25 \%$ crustal component, $x_{\text {crust }}$ varies for each element, incompatible elements being dominantly controlled by the crustal component ( $x_{\text {crust }}$ being as high as $99 \%$ for $\mathrm{Rb}, \mathrm{Ba}, \mathrm{Th}, \mathrm{U}$ as the initial mantle contains very little of these) whilst compatible elements mostly come from the mantle (e.g. $97 \%$ of the $\mathrm{MgO}, \mathrm{Cr}$ and $\mathrm{Ni}$ is of mantle origin). Importantly, the five most abundant major oxides in the source $\left(\mathrm{SiO}_{2}, \mathrm{Al}_{2} \mathrm{O}_{3}\right.$, $\mathrm{MgO}, \mathrm{FeO}, \mathrm{CaO}$; ca. $95 \%$ of the bulk mass) are dominantly of mantle origin ( $x_{\text {crust }}$ is generally $<30 \%$ ) because of the limited concentration contrast (less than one order of magnitude) between mantle and crust and the low mass fraction of the crustal component in the hybrid source (Fig. 8). As a direct and critical consequence of this, assuming that the proportion of "crust" vs. "mantle" atoms for each element does not change during melting of the hybrid source, the bulk mass fraction of PCMM that derives from the crustal component is low. Typically, for three representative PCMM samples (from a Late-Archean terrane and the Variscan and Himalayan orogens), it lies between $15-21 \%$ and $31-38 \%$, for respectively $10 \%$ and $25 \%$ of crustal materials in the hybrid source (see Fig. 8), meaning that $>62 \%$ of the bulk mass of these samples are of mantle origin and thus represent new additions to the crust.

This first-order calculation implicitly presumes that "crust" and "mantle" atoms of each element are equally distributed over mineral phases in the hybrid source so that $x_{\text {crust }}$ keeps constant during melting. This is likely over-simplistic for trace elements, especially the dominantly crust-derived elements that would be preferentially partitioned into the phases formed via metasomatic reactions such as pyroxenes, amphibole and phlogopite (Prouteau et al., 2001; Rapp et al., 2010), which in turn preferentially contribute to melting reactions (Condamine and Médard, 2014; Mallik et al., 2015). However, for major oxides, $x_{\text {crust }}$ likely remains constant throughout the process. Indeed, metasomatic reactions would randomly use both "crust" and "mantle" elements to form new minerals and, even if not, solid-state diffusion, phase recrystallization and mixing enhanced by high-temperature deformation (Linckens et al., 2014) would smooth any significant difference of $x_{\text {crust }}$ from a mineral to another. Moreover, even considering an artificial two-fold increase in the proportion of "crustal" $\mathrm{SiO}_{2}$ and $\mathrm{Al}_{2} \mathrm{O}_{3}$ between a highly-enriched mantle composition (25\% crustal component) and the melt owing to their potential concentration in newly formed phlogopite, amphibole and pyroxene, the mass fraction of crust-derived elements in the three PCMM samples used for calculation would not exceed 50-63\%. These are definitely maximum values since this scenario is somewhat extreme. Therefore, it is reasonable to conclude that the proportion of reworked crustal materials in PCMM does not exceed $63 \%$ and is most often, as calculated earlier, between 15 and 38\%.

Paradoxically, most PCMM (especially the three specimens used in the calculations) display markedly negative zircon $\varepsilon \mathrm{Hf}_{\mathrm{t}}$. Then, from an $\mathrm{Hf}$ isotope perspective alone, those rocks apparently cor- 

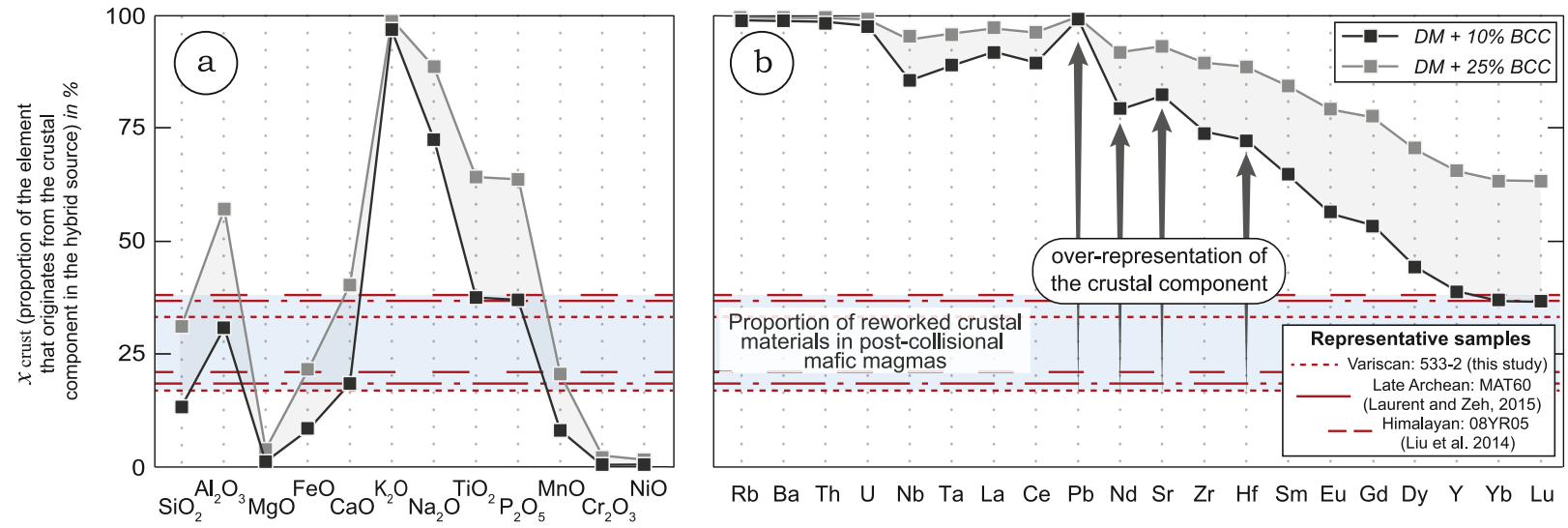

$\mathrm{Rb} \mathrm{Ba}$ Th $\mathrm{U}$ Nb Ta La Ce Pb Nd Sr Zr Hf Sm Eu Gd Dy $\mathrm{Y}$ Yb Lu

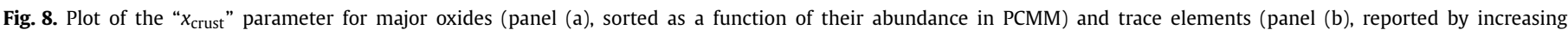

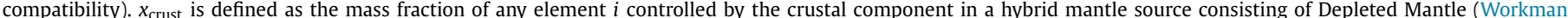

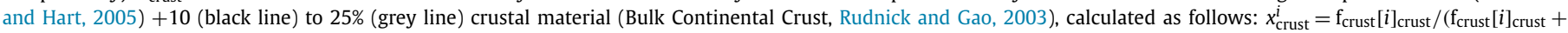

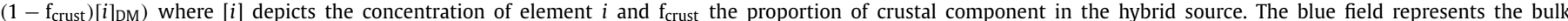

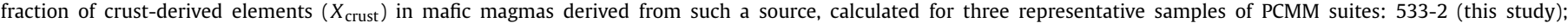

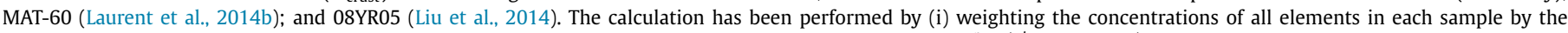
corresponding values of $x_{\text {crust }}$, and (ii) summing up the resulting values. See text for discussion. $X_{\text {crust }}=\sum_{i=1}^{\mathrm{n}}\left(x_{\text {crust }}^{i} \cdot[i]_{\mathrm{PCMM}}\right)$.

respond to pure reworking of former crustal lithologies. This discrepancy simply results from the large dominance of the crustal component on the incompatible trace element budget (including the radiogenic tracers $\mathrm{Sr}, \mathrm{Nd}, \mathrm{Hf}, \mathrm{Pb}$ ) in the hybrid source (Fig. 8). Typically, the Hf budget in the source of PCMM consists of $72-89 \%$ non-radiogenic "crustal" Hf and only $11-28 \%$ radiogenic "mantle" Hf. Therefore, as long as incompatible element tracers are considered, PCMM would bear a "crustal" signature and the mantle contribution to their origin, although dominant in terms of mass, would be invisible.

\subsection{Consequences for crustal growth}

As demonstrated earlier (Table 1), PCMM have been emplaced during or at the end of continental collision since the late Archean (Bonin, 2004; Fowler and Rollinson, 2012; Laurent et al., 2014a), specifically at each stage of supercontinent amalgamation. They are therefore a systematic magmatic feature of the orogenic cycle, just as MORB, arc magmas or collisional granites are, and their significance for global crustal evolution must be addressed.

Although the surface expression of PCMM is limited, it has been demonstrated in several settings that they would actually represent the parental magmas of much more voluminous granitoid suites via fractionation (Fowler and Henney, 1996; Küster and Harms, 1998; Laurent et al., 2013; Moyen et al., in press) and/or limited interaction with coeval crustal melts (Clemens et al., 2009; Janoušek et al., 2004; Laurent et al., 2014a; Parat et al., 2009). In terms of mass balance, these two processes are antagonists: silicic liquids will represent only a fraction of the initial mass of mafic magma in the case of fractionation, whereas interaction with crustal material represents a mass addition to PCMM to form granitoids. Hence, it is reasonable to consider that in a given orogenic system, the initial volume of PCMM was roughly equivalent to that of their genetically related granitoids. According to Moyen et al. (in press), PCMM-derived granitoids represent ca. $10 \%$ of exposed rocks in the Variscan belt; given that 62 to $85 \%$ of the bulk mass of PCMM consist of elements extracted from the mantle (see section 4.3), and assuming that surface exposure reflects the repartition of lithologies at depth, then 6.2 to $8.5 \%$ of the bulk mass of the Variscan crust represents new additions from the mantle by PCMM.

At first glance, this estimate appears modest in comparison with arc settings, in which the large majority of the bulk crustal volume is derived from the differentiation of mantle-derived mafic magmas (Jagoutz and Kelemen, 2015). However, mantle-derived magmatic rocks only become long-term additions to the continental volume if they are subsequently preserved: while a small fraction of arc granitoids may be captured in collisional orogens (Condie et al., 2011), the majority of them are readily recycled into the mantle shortly after their formation owing to sediment subduction and/or subduction erosion (Stern and Scholl, 2010). In contrast, PCMM and derivatives represent small volumes of only partly mantle-derived magmas, but because they are shielded in the core of newly formed continental masses, they have a much greater preservation potential in the geological record (Hawkesworth et al., 2010). As a result, they may represent significant contributors to long-term crustal growth.

Recently, the problem of crustal growth through time has been extensively addressed via the statistical analysis of global zircon Hf (Belousova et al., 2010; Condie et al., 2011) or coupled Hf-O (Dhuime et al., 2012) isotopic databases: Hf model ages are used to determine the timing of crust formation, and $\mathrm{O}$ isotopes to distinguish zircons formed in granitoids reworking a "juvenile" source $\left(\delta^{18} \mathrm{O}=5.5 \pm 1.0 \% 0\right)$ or a "mixed" sedimentary source $\left(\delta^{18} \mathrm{O}>\right.$ $6.5 \%$ ) (e.g. Hawkesworth and Kemp, 2006). The reliability of this approach has been questioned recently, especially because $\mathrm{Hf}$ and $\mathrm{O}$ isotopes in zircon reflect in most cases the contribution of multiple components in the origin of their host magma (magma mixing, heterogeneous sources, crustal contamination) (Payne et al., 2016; Roberts and Spencer, 2015). The case of PCMM raises an even more problematic issue, showing that igneous material representing a non-negligible contribution to long-term crustal growth may not have DM-like Hf isotope compositions and "pristine mantle" $\mathrm{O}$ isotope compositions because of the small proportions of crustal (possibly sedimentary) material in their hybrid mantle source.

Several lines of evidence suggest that, despite their limited volume, zircons from PCMM and derivatives represent a sizeable proportion of global detrital zircon databases. First, because of their selective preservation (Hawkesworth et al., 2010), zircons from collision-related igneous rocks dominate the detrital populations in sedimentary rocks wherever recent or ancient orogenic crust is present in the catchment area (Spencer et al., 2015). Second, because of their high $\mathrm{Zr}$ contents (370 ppm in average in the eastern FMC), rocks from the PCMM suite have a higher zircon fertility factor ("ZFF" of Dickinson, 2008) than other collisional granites (150 ppm $\mathrm{Zr}$ in the eastern FMC; Moyen et al., in press). 
Third, magmatic zircons from these rocks show a greater proportion ( $~ 80 \%)$ of concordant $\mathrm{U}-\mathrm{Pb}$ ages compared to those of purely crust-derived ("S-type") granites ( 50\%) (Couzinié et al., 2014; Laurent et al., 2015), such that in a detrital zircon population, the probability to discard zircons from PCMM and derivatives because of U-Pb discordance (Nemchin and Cawood, 2005) is smaller than for S-type granites. To illustrate the two latter issues, the erosion of the Variscan crust, assuming that the latter consists of $10 \%$ PCMM-derived granitoids ( $\mathrm{ZFF}=2.5 ; 80 \% \mathrm{U}-\mathrm{Pb}$ concordance); $30 \%$ crust-derived granites ( $\mathrm{ZFF}=1 ; 50 \% \mathrm{U}-\mathrm{Pb}$ concordance); and $60 \%$ of metamorphic and sedimentary rocks $(\mathrm{ZFF}=1 ; 67 \% \mathrm{U}-\mathrm{Pb}$ concordance), would yield a detrital zircon population in which the final, U-Pb concordant dataset contains a minimum of $27 \%$ data from PCMM-derived material - notwithstanding the likely possibility that metamorphic and sedimentary rocks may contain zircons from reworked, earlier PCMM and related granites, exactly for the same reasons.

Therefore, zircons derived from PCMM, their differentiated products and any igneous and sedimentary material derived from them, would significantly bias the crustal growth signal of global detrital zircon databases, in two distinct ways:

(1) Zircons from any PCMM crystallized at time $t$ would have been either discarded (non-mantle $\delta^{18} \mathrm{O}$ resulting from the involvement of sedimentary components) or attributed to ancient events of crust formation because of non-radiogenic Hf isotope compositions (and old Hf model ages). Although the latter feature certainly reflects reworking of older crust to some extent, this reworking is over-estimated because the mantle contribution at time $t$ cannot be resolved by $\mathrm{Hf}$ isotopes alone (see section 4.3).

(2) If PCMM-derived crustal material is reworked by later magmatic events, then the calculation of model ages based on DM for zircons formed in these younger magmas is inappropriate since their crustal source had a non-DM Hf isotopic composition.

Both would have the same global effect, i.e. skewing crustal growth models towards an over-estimation of ancient crustal growth with respect to younger crust formation. Specifically, because PCMM are present on Earth since the late Archean (Table 1), post-Archean crustal growth rates may be significantly underestimated.

\section{Conclusions}

1. PCMM are ubiquitous in all continental collision settings since the late Archean and are characterized by a dual geochemistry, with high contents in both compatible, "mantle-hosted" elements $\left(\mathrm{FeO}_{\mathrm{t}}+\mathrm{MgO}, \mathrm{Ni}, \mathrm{Cr}\right)$ and incompatible, "crust-hosted" elements (LILE, REE, HFSE).

2. As illustrated by the case study from the eastern FMC, PCMM originated from low-degree partial melting of a phlogopite(and/or amphibole-) bearing peridotite/pyroxenite. In the FMC, the non-radiogenic $\varepsilon \mathrm{Hf}_{(\mathrm{t})}(-2$ to -9$)$ and elevated $\delta^{18} \mathrm{O}_{\mathrm{SMOW}}$ ( +6 to $+10 \%$ ) of PCMM zircons suggest that this mantle source was contaminated by 10 to $25 \%$ of subducted continental shelf sediments derived from Precambrian crust, shortly prior to melting.

3. Mass balance calculations indicate that the incompatible trace element budget (including radiogenic isotope tracers $\mathrm{Sr}, \mathrm{Nd}$, $\mathrm{Hf}, \mathrm{Pb}$ ) of the PCMM source is mainly controlled by the crustal component. Therefore, resulting magmas display "crust-like" non-radiogenic isotope compositions even though 62 to $85 \%$ of their bulk mass originates from the mantle component and represents new addition to the crust.
4. PCMM have contributed to crustal growth since the late Archean because they are the parent of voluminous granitoid suites and have a high preservation potential in the geological record. Owing to their peculiar hybrid origin, this contribution cannot be resolved in global crustal growth models based only on zircon $\mathrm{Hf}$ and $\mathrm{O}$ isotopes, such that post-Archean crustal growth may be significantly under-estimated.

\section{Acknowledgements}

We acknowledge financial support from an ERC grant (StG 279828, project MASE to J. van Hunen), two PNP grants from French CNRS ("Différentiation et évolution de la croûte tardi orogénique", 2014 and "Quantification de la durée d'un épisode de fusion partielle en contexte de désépaississement tardi-orogénique", 2016), the Deutsche Forschungsgemeinschaft (grant Zeh424/11-2 to A.Z.) and the Deutscher Akademischer Austauschdienst (grant A/13/70682 to O.L.). A.V. acknowledges funding by the Labex VOLTAIRE (ANR-10-LABX-100-01). V. Gardien provided two samples for this study. D. Garcia kindly supplied his database and guided us in the field. A. Vézinet, M. Benoit and E. Bruand assisted during zircon separation procedures. Helpful discussions with V. Janoušek and G. Stevens were much appreciated. A. Gerdes assisted during $\mathrm{Hf}$ analytical sessions and P. Montero performed zircon imaging and SHRIMP measurements. This contribution is IBERSIMS publication $\mathrm{N}^{\circ} 35$. We are grateful to A. Yin for editorial handling. C.L. Farmer and S. Wilde provided thorough and constructive reviews; R. Rudnick, P. Cawood and an anonymous reviewer provided insightful comments on an earlier version of this manuscript - may they all be thanked.

\section{Appendix A. Supplementary material}

Supplementary material related to this article can be found online at http://dx.doi.org/10.1016/j.epsl.2016.09.033.

\section{References}

Albert, R. Arenas, R., Gerdes, A., Sanchez Martinez, S., Marko, L., 2015. Provenance of the HP-HT subducted margin in the Variscan belt (Cabo Ortegal Complex, NW Iberian Massif). J. Metamorph. Geol. 33, 959-979.

Andersson, U.B., Eklund, O., Fröjdö, S., Konopelko, D., 2006. 1.8 Ga magmatism in the Fennoscandian Shield; lateral variations in subcontinental mantle enrichment. Lithos 86, 110-136.

Arndt, N.T., 2013. Formation and evolution of the continental crust. Geochem. Perspect. 2 (3), 405-533.

Arndt, N.T., Goldstein, S.L., 1987. Use and abuse of crust-formation ages. Geology 15, 893-895.

Atherton, M.P., Ghani, A.A., 2002. Slab breakoff: a model for Caledonian, Late Granite syn-collisional magmatism in the orthotectonic (metamorphic) zone of Scotland and Donegal, Ireland. Lithos 62.

Belousova, E.A., Kostitsyn, Y.A., Griffin, W.L., Begg, G.C., O’Reilly, S.Y., Pearson, N.J. 2010. The growth of the continental crust: constraints from zircon Hf-isotope data. Lithos 119, 457-466.

Bindeman, I., 2008. Oxygen isotopes in mantle and crustal magmas as revealed by single crystal analysis. Rev. Mineral. Geochem. 69, 445-478.

Bonin, B., 2004. Do coeval mafic and felsic magmas in post-collisional to withinplate regimes necessarily imply two contrasting, mantle and crustal, sources? A review. Lithos 78, 1-24.

Bouilhol, P., Jagoutz, O., Hanchar, J.M., Dudas, F.O., 2013. Dating the India-Eurasia collision through arc magmatic records. Earth Planet. Sci. Lett. 366, 163-175.

Bouilhol, P., Schaltegger, U., Chiaradia, M., Ovtcharova, M., Stracke, A., Burg, J.-P., Dawood, H., 2011. Timing of juvenile arc crust formation and evolution in the Sapat Complex (Kohistan-Pakistan). Chem. Geol. 280, 243-256.

Bouvier, A., Vervoort, J.D., Patchett, P.J., 2008. The Lu-Hf and Sm-Nd isotopic composition of CHUR: constraints from unequilibrated chondrites and implications for the bulk composition of terrestrial planets. Earth Planet. Sci. Lett. 273 (1-2), 48-57.

Campbell, I.H., Allen, C., 2008. Formation of supercontinents linked to increases in atmospheric oxygen. Nat. Geosci. 1, 554-558.

Campbell, I.H., Stepanov, A.S., Liang, H.-Y., Allen, C.M., Norman, M.D., Zhang, Y.-Q. Xie, Y.-W., 2014. The origin of shoshonites: new insights from the Tertiary highpotassium intrusions of eastern Tibet. Contrib. Mineral. Petrol. 167 (3), 1-22. 
Chantraine, J., Autran, A., Cavelier, C., 1996. Carte géologique de la France à l'échelle du millionième, $6^{\text {ème }}$ édition. BRGM, Orléans.

Chelle-Michou, C., Laurent, O., Moyen, J.F., Block, S., Gardien, V., Paquette, J.L. Couzinié, S., 2015. New U-Pb and Hf zircon data from the eastern Massif Central: from Gondwana to Pangea in a nutshell. Géol. Fr. 1, 37-38.

Chung, S.-L., Chu, M.-F., Zhang, Y., Xie, Y., Lo, C.-H., Lee, T.-Y., Lan, C.-Y., Li, X., Zhang, Q., Wang, Y., 2005. Tibetan tectonic evolution inferred from spatial and temporal variations in post-collisional magmatism. Earth-Sci. Rev. 68, 173-196.

Clemens, J.D., Darbyshire, D.P.F., Flinders, J., 2009. Sources of post-orogenic calcalkaline magmas: the Arrochar and Garabal Hill-Glen Fyne complexes, Scotland. Lithos 112, 524-542.

Conceição, R., Green, D.H., 2004. Derivation of potassic (shoshonitic) magmas by decompression melting of phlogopite + pargasite lherzolite. Lithos 72, 209-229.

Condamine, P., Médard, E., 2014. Experimental melting of phlogopite-bearing mantle at $1 \mathrm{GPa}$ : implications for potassic magmatism. Earth Planet. Sci. Lett. 397, $80-92$.

Condie, K.C., Bickford, M.E., Aster, R.C., Belousova, E., Scholl, D.W., 2011. Episodic zircon ages, $\mathrm{Hf}$ isotopic composition, and the preservation rate of continental crust. Geol. Soc. Am. Bull. 123, 951-957.

Couzinié, S., Moyen, J.F., Villaros, A., Paquette, J.L., Scarrow, J.H., Marignac, C., 2014 Temporal relationships between $\mathrm{Mg}-\mathrm{K}$ mafic magmatism and catastrophic melting of the Variscan crust in the southern part of Velay Complex (Massif Central, France). J. Geosci., 69-86.

Davidson, J., 1987. Crustal contamination versus subduction zone enrichment: examples from the Lesser Antilles and implications for mantle source compositions of island arc volcanic rocks. Geochim. Cosmochim. Acta 51, 2185-2198.

Dhuime, B., Hawkesworth, C.J., Cawood, P.A., Storey, C.D., 2012. A change in the geodynamics of continental growth 3 billion years ago. Science 335, 1334-1336.

Dickinson, W.R., 2008. Impact of differential zircon fertility of granitoid basement rocks in North America on age populations of detrital zircons and implications for granite petrogenesis. Earth Planet. Sci. Lett. 275, 80-92.

Downes, H., Dupuy, C., Leyreloup, A.F., 1990. Crustal evolution of the Hercynian belt of Western Europe: evidence from lower-crustal granulitic xenoliths (French Massif Central). Chem. Geol. 83, 209-231.

Faure, M., Bé Mézème, E., Cocherie, A., Rossi, P., Chemenda, A., Boutelier, D., 2008 Devonian geodynamic evolution of the Variscan Belt, insights from the French Massif Central and Massif Armoricain. Tectonics 27, TC2005.

Fowler, M., Henney, P.J., 1996. Mixed Caledonian appinite magmas: implications for lamprophyre fractionation and high $\mathrm{Ba}-\mathrm{Sr}$ granite genesis. Contrib. Mineral. Petrol. 126, 199-215.

Fowler, M., Rollinson, H., 2012. Phanerozoic sanukitoids from Caledonian Scotland: implications for Archean subduction. Geology 40, 1079-1082.

Gaetani, G.A., Grove, T.L., 1998. The influence of water on melting of mantle peridotite. Contrib. Mineral. Petrol. 131, 323-346.

Green, D.H., 2015. Experimental petrology of peridotites, including effects of water and carbon on melting in the Earth's upper mantle. Phys. Chem. Miner. 42 95-122.

Grégoire, M., Moine, B.N., O’Reilly, S.Y., Cottin, J.-Y., Giret, A., 2000. Trace element residence and partitioning in mantle xenoliths metasomatized by highly alkaline, silicate- and carbonate-rich melts (Kerguelen Islands, Indian Ocean). J. Petrol. 41, 477-509.

Griffin, W.L., Wang, X., Jackson, S.E., Pearson, N.J., O’Reilly, S.Y., Xu, X.-S., Zhou, X. 2002. Zircon chemistry and magma mixing, SE China: in-situ analysis of Hf isotopes, Tonglu and Pingtan igneous complexes. Lithos 61, 237-269.

Guo, Z., Wilson, M., Zhang, L., Zhang, M., Cheng, Z., Liu, J., 2014. The role of subduction channel mélanges and convergent subduction systems in the petrogenesis of post-collisional K-rich mafic magmatism in NW Tibet. Lithos 198-199 184-201.

Hagen-Peter, G., Cottle, J.M., Tulloch, A.J., Cox, S.C., 2015. Mixing between enriched lithospheric mantle and crustal components in a short-lived subduction-related magma system, Dry Valleys area, Anatarctica: insights from U-Pb geochronology, Hf isotopes and whole-rock geochemistry. Lithosphere 7 (2), 174-188.

Hawkesworth, C., Cawood, P., Kemp, T., Storey, C., Dhuime, B., 2009. A matter of preservation. Science $323,49-50$.

Hawkesworth, C.J., Dhuime, B., Pietranik, A.B., Cawood, P.A., Kemp, A.I.S., Storey, C.D., 2010. The generation and evolution of the continental crust. J. Geol. Soc (Lond.) 167, 229-248.

Hawkesworth, C.J., Kemp, A.I.S., 2006. Using hafnium and oxygen isotopes in zircons to unravel the record of crustal evolution. Chem. Geol. 226, 144-162.

Heilimo, E., Halla, J., Andersen, T., Huhma, H., 2013. Neoarchean crustal recycling and mantle metasomatism: $\mathrm{Hf}-\mathrm{Nd}-\mathrm{Pb}-\mathrm{O}$ isotope evidence from sanukitoids of the Fennoscandian shield. Precambrian Res. 228, 250-266.

Hermann, J., Rubatto, D., 2009. Accessory phase control on the trace element signature of sediment melts in subduction zones. Chem. Geol. 265, 512-526.

Holub, F.V., 1997. Ultrapotassic plutonic rocks of the durbachite series in the Bohemian Massif: petrology, geochemistry and petrogenetic interpretation. $\mathrm{Sb}$. Geol. Věd, Ložisk. Geol. Mineral. 31, 5-26.

Jagoutz, O., Kelemen, P.B., 2015. Role of arc processes in the formation of continental crust. Annu. Rev. Earth Planet. Sci. 43, 363-404.

Janoušek, V., Braithwaite, C.J.R., Bowes, D.R., Gerdes, A., 2004. Magma-mixing in the genesis of Hercynian calc-alkaline granitoids: an integrated petrographic and geochemical study of the Sázava intrusion, Central Bohemian Pluton, Czech Republic. Lithos 78, 67-99.

Janoušek, V., Holub, F.V., 2007. The causal link between HP-HT metamorphism and ultrapotassic magmatism in collisional orogens: case study from the Moldanubian Zone of the Bohemian Massif. Proc. Geol. Assoc. 118, 75-86.

Kemp, A.I., Hawkesworth, C.J., Paterson, B.A., Kinny, P.D., 2006. Episodic growth of the Gondwana supercontinent from hafnium and oxygen isotopes in zircon. Nature 439, 580-583.

Küster, D., Harms, U., 1998. Post-collisional potassic granitoids from the southern and northwestern parts of the Late Neoproterozoic East African Orogen: a review. Lithos 45, 177-195

Lancaster, P.J., Storey, C.D., Hawkesworth, C.J., Dhuime, B., 2011. Understanding the roles of crustal growth and preservation in the detrital zircon record. Earth Planet. Sci. Lett. 305, 405-412.

Lardeaux, J.M., Ledru, P., Daniel, I., Duchene, S., 2001. The Variscan French Massif Central - a new addition to the ultra-high pressure metamorphic "club": exhumation processes and geodynamic consequences. Tectonophysics 332, 143-167.

Laurent, O., Couzinié, S., Vanderhaeghe, O., Zeh, A., Moyen, J.F., Villaros, A., Gardien, V., 2015. U-Pb dating of Variscan igneous rocks from the eastern French Massif Central: southward migration of coeval crust- and mantle-melting witnesses late-orogenic slab retreat. Géol. Fr. 1, 82-83.

Laurent, O., Doucelance, R., Martin, H., Moyen, J.-F., 2013. Differentiation of the lateArchaean sanukitoid series and some implications for crustal growth: insights from geochemical modelling on the Bulai pluton, Central Limpopo Belt, South Africa. Precambrian Res. 227, 186-203.

Laurent, O., Martin, H., Doucelance, R., Moyen, J.F., Paquette, J.L., 2011. Geochemistry and petrogenesis of high-K "sanukitoids" from the Bulai pluton, Cenral Limpopo Belt, South Africa: implications for geodynamic changes at the Archaean-Proterozoic boundary. Lithos 123, 73-91.

Laurent, O., Martin, H., Moyen, J.F., Doucelance, R., 2014a. The diversity and evolution of late-Archean granitoids: evidence for the onset of "modern-style" plate tectonics between 3.0 and $2.5 \mathrm{Ga}$. Lithos 205, 208-235.

Laurent, O., Rapopo, M., Stevens, G., Moyen, J.F., Martin, H., Doucelance, R., Bosq, C., 2014b. Contrasting petrogenesis of $\mathrm{Mg}-\mathrm{K}$ and $\mathrm{Fe}-\mathrm{K}$ granitoids and implications for post-collisional magmatism: case study from the Late-Archean Matok pluton (Pietersburg block, South Africa). Lithos 196-197, 131-149.

Laurent, O., Zeh, A., 2015. A linear Hf isotope-age array despite different granitoid sources and complex Archean geodynamics: example from the Pietersburg block (South Africa). Earth Planet. Sci. Lett. 430, 326-338.

Ledru, P., Courrioux, G., Dallain, C., Lardeaux, J.M., Montel, J.M., Vanderhaeghe, O., Vitel, G., 2001. The Velay dome (French Massif Central): melt generation and granite emplacement during orogenic evolution. Tectonophysics 342, 207-237.

Lee, C.-T.A., Harbert, A., Leeman, W.P., 2007. Extension of lattice strain theory to mineral/mineral rare-earth element partitioning: an approach for assessing disequilibrium and developing internally consistent partition coefficients between olivine, orthopyroxene, clinopyroxene and basaltic melt. Geochim. Cosmochim. Acta 71, 481-496.

Liégeois, J.-P., Navez, J., Hertogen, J., Black, R., 1998. Contrasting origin of postcollisional high-K calc-alkaline and shoshonitic versus alkaline and peralkaline granitoids. The use of sliding normalization. Lithos 45, 1-28.

Linckens, J., Bruijn, R.H.C., Skemer, P., 2014. Dynamic recrystallization and phase mixing in experimentally deformed peridotite. Earth Planet. Sci. Lett. 388, $134-142$.

Linnemann, U., Gerdes, A., Hofmann, M., Marko, L., 2014. The Cadomian Orogen: Neoproterozoic to Early Cambrian crustal growth and orogenic zoning along the periphery of the West African Craton-constraints from U-Pb zircon ages and $\mathrm{Hf}$ isotopes (Schwarzburg Antiform, Germany). Precambrian Res. 244, 236-278.

Liu, D., Zhao, Z., Zhu, D.-C., Niu, Y., DePaolo, D.J., Harrison, T.M., Mo, X., Dong, G., Zhou, S., Sun, C., Zhang, Z., Liu, J., 2014. Postcollisional potassic and ultrapotassic rocks in southern Tibet: mantle and crustal origins in response to India-Asia collision and convergence. Geochim. Cosmochim. Acta 143, 207-231.

Lowe, D.R., Tice, M.M., 2004. Geologic evidence for Archean atmospheric and climatic evolution: fluctuating levels of $\mathrm{CO}_{2}, \mathrm{CH}_{4}$, and $\mathrm{O}_{2}$ with an overriding tectonic control. Geology 32, 493-496.

Mallik, A., Nelson, J., Dasgupta, R., 2015. Partial melting of fertile peridotite fluxed by hydrous rhyolitic melt at 2-3 GPa: implications for mantle wedge hybridization by sediment melt and generation of ultrapotassic magmas in convergent margins. Contrib. Mineral. Petrol. 169 (5), 1-24.

McCulloch, M.T., Wasserburg, G.J., 1978. Sm-Nd and Rb-Sr chronology of continental crust formation. Science 200, 1003-1011.

McDonough, W.F., Sun, S.-s., 1995. The composition of the Earth. Chem. Geol. 120, 223-253.

McKenzie, D., O'Nions, R.K., 1991. Partial melt distributions from inversion of rare Earth element concentrations. J. Petrol. 32 (5), 1021-1091.

Melleton, J., Cocherie, A., Faure, M., Rossi, P., 2010. Precambrian protoliths and Early Paleozoic magmatism in the French Massif Central: U-Pb data and the North Gondwana connection in the West European Variscan belt. Gondwana Res. 17, 13-25.

Mengel, K., Green, D.H., 1989. Stability of amphibole and phlogopite in metasomatized peridotite under water-saturated and water-undersaturated conditions. In: 
Ross, J. (Ed.), Kimberlites and Related Rocks, vol. 1, Their Composition, Occurrence, Origin and Emplacement. Blackwell, Melbourne, pp. 571-581.

Middlemost, E.A.K., 1994. Naming materials in the magma/igneous rock system. Earth-Sci. Rev. 37, 215-224.

Moyen, J.F., Laurent, O., Chelle-Michou, C., Couzinié, S., Vanderhaeghe, O., Zeh, A., Villaros, A., Gardien, V., in press. Collision vs. subduction-related magmatism: two contrasting sites of granite formation and implications for crustal growth. Lithos. http://dx.doi.org/10.1016/j.lithos.2016.09.018.

Murphy, J.B., 2013. Appinite suites: a record of the role of water in the genesis, transport, emplacement and crystallization of magma. Earth-Sci. Rev. 119, 35-59.

Naeraa, T., Schersten, A., Rosing, M.T., Kemp, A.I., Hoffmann, J.E., Kokfelt, T.F., Whitehouse, M.J., 2012. Hafnium isotope evidence for a transition in the dynamics of continental growth 3.2 Gyr ago. Nature 485, 627-630.

Nelson, D.R., 1992. Isotopic characteristics of potassic rocks: evidence for the involvement of subducted sediments in magma genesis. Lithos 28, 403-420.

Nemchin, A.A., Cawood, P.A., 2005. Discordance of the U-Pb system in detrital zircons: implication for provenance studies of sedimentary rocks. Sediment. Geol. 182, 143-162.

Parat, F., Holtz, F., René, M., Almeev, R., 2009. Experimental constraints on ultrapotassic magmatism from the Bohemian Massif (durbachite series, Czech Republic). Contrib. Mineral. Petrol. 159, 331-347.

Patchett, P.J., Kouvo, O., Hedge, C.E., Tatsumoto, M., 1982. Evolution of continental crust and mantle heterogeneity: evidence from Hf isotopes. Contrib. Mineral. Petrol. 78, 279-297.

Payne, J.L., McInerney, D.J., Barovich, K.M., Kirkland, C.L., Pearson, N.J., Hand, M., 2016. Strengths and limitations of zircon Lu-Hf and O isotopes in modelling crustal growth. Lithos 248-251, 175-192.

Peccerillo, A., Taylor, S.R., 1976. Geochemistry of Eocene calc-alkaline volcanic rocks from the Kastamonu area, Northern Turkey. Contrib. Mineral. Petrol. 58, 63-81.

Pin, C., Lancelot, J., 1982. U-Pb dating of an early paleozoic bimodal magmatism in the French Massif Central and of its further metamorphic evolution. Contrib. Mineral. Petrol. 79, 1-12.

Pin, C., Paquette, J.L., 1997. A mantle-derived bimodal suite in the Hercynian Belt: $\mathrm{Nd}$ isotope and trace element evidence for a subduction-related rift origin of the Late Devonian Brévenne metavolcanics, Massif Central (France). Contrib. Mineral. Petrol. 129, 222-238.

Pin, C., Paquette, J.L., 2002. Sr-Nd isotope and trace element evidence for a Late Devonian active margin in northern Massif Central (France). Geodin. Acta 15, 63-77.

Plank, T., 2005. Constraints from thorium/lanthanum on sediment recycling at subduction zones and the evolution of the continents. J. Petrol. 46, 921-944.

Plank, T., Langmuir, C.H., 1998. The chemical composition of subducting sediment and its conseqiences for the crust and mantle. Chem. Geol. 145, 325-394.

Prelevic, D., Akal, C., Foley, S.F., Romer, R.L., Stracke, A., Van Den Bogaard, P., 2012. Ultrapotassic mafic rocks as geochemical proxies for post-collisional dynamics of orogenic lithospheric mantle: the case of Southwestern Anatolia, Turkey. J. Petrol. 53, 1019-1055.

Prouteau, G., Scaillet, B., Pichavant, M., Maury, R., 2001. Evidence for mantle metasomatism by hydrous silicic melts derived from subducted oceanic crust. Nature 410, 197-200.

Rapp, R.P., Norman, M.D., Laporte, D., Yaxley, G.M., Martin, H., Foley, S.F., 2010. Continent formation in the Archean and chemical evolution of the cratonic lithosphere: melt-rock reaction experiments at 3-4 GPa and petrogenesis of Archean Mg-diorites (sanukitoids). J. Petrol. 51, 1237-1266.

Roberts, N.M.W., Slagstad, T., Parrish, R.R., Norry, M.J., Marker, M., Horstwood, M.S.A., 2012. Sedimentary recycling in arc magmas: geochemical and U-Pb-HfO constraints on the Mesoproterozoic Suldal Arc, SW Norway. Contrib. Mineral. Petrol. 165, 507-523.

Roberts, N.M.W., Spencer, C.J., 2015. The zircon archive of continent formation through time. In: Special Publications, London Geological Society, vol. 389, pp. 197-225.

Rudnick, R.L., Gao, S., 2003. Composition of the continental crust. In: Rudnick, R.L. (Ed.), The Crust. Elsevier-Pergamon, Oxford, pp. 1-64.

Rutanen, H., Andersson, U.B., Väisänen, M., Johansson, Å., Fröjdö, S., Lahaye, Y., Eklund, O., 2011. 1.8 Ga magmatism in southern Finland: strongly enriched man- tle and juvenile crustal sources in a post-collisional setting. Int. Geol. Rev. 53, 1622-1683.

Sabatier, H., 1991. Vaugnerites: special lamprophyre derived mafic enclaves in some Hercynian granites from Western and Central Europe. In: Didier, J., Barbarin, B. (Eds.), Enclaves and Grantie Petrology. Elsevier, Amsterdam, pp. 63-81.

Siebel, W., Chen, F., 2009. Zircon Hf isotope perspective on the origin of granitic rocks from eastern Bavaria, SW Bohemian Massif. Int. J. Earth Sci. 99, 993-1005.

Spencer, C.J., Cawood, P.A., Hawkesworth, C.J., Prave, A.R., Roberts, N.M.W. Horstwood, M.S.A., Whitehouse, M.J., 2015. Generation and preservation of continental crust in the Grenville Orogeny. Geosci. Front. 6, 357-372.

Stern, R.J., Scholl, D.W., 2010. Yin and Yang of continental crust creation and destruction by plate tectonic processes. Int. Geol. Rev. 52, 1-31.

Sun, S.s., McDonough, W.F., 1989. Chemical and isotopic systematics of oceanic basalts: implications for mantle composition and processes. In: Saunders, A.D. Norry, M.J. (Eds.), Magmatism in the Ocean Basins. Geological Society, London, pp. 313-345.

Taylor, S.R., McLennan, S.M., 1985. The Continental Crust: Its Composition and Evolution. Blackwell, Oxford, 312 pp.

Tenner, T.J., Hirschmann, M.M., Humayun, M., 2012. The effect of $\mathrm{H}_{2} \mathrm{O}$ on partial melting of garnet peridotite at $3.5 \mathrm{GPa}$. Geochem. Geophys. Geosyst. 13 (3).

Thibault, Y., Edgar, A.D., Lloyd, F.E., 1992. Experimental investigation of melts from a carbonated phlogopite lherzolite: implications for metasomatism in the continental lithospheric mantle. Am. Mineral. 77, 784-794.

Turpin, L., Velde, D., Pinte, G., 1988. Geochemical comparison between minettes and kersantites from the Western European Hercynian orogen: trace element and $\mathrm{Pb}-\mathrm{Sr}-\mathrm{Nd}$ isotope constraints on their origin. Earth Planet. Sci. Lett. 87, 73-86.

Valley, J., Graham, C.M., Harte, B., Eiler, J.M., Kinny, P.D., 1998. Ion microprobe analysis of oxygen, carbon, and hydrogen isotope ratios. In: Applications of Microanalytical Techniques to Understanding Mineralizing Processes. Society of Economic Geologists, Littleton, pp. 73-98.

Vervoort, J., Blichert-Toft, J., 1999. Evolution of the depleted mantle: Hf isotope evidence from juvenile rocks through time. Geochim. Cosmochim. Acta 63, 533-556.

Villaseca, C., Orejana, D., Belousova, E., Armstrong, R.A., Pérez-Soba, C., Jeffries, T.E., 2010. U-Pb isotopic ages and Hf isotope composition of zircons in Variscan gabbros from central Spain: evidence of variable crustal contamination. Mineral. Petrol. 101 (3-4), 151-167.

von Raumer, J.F., Finger, F., Veselá, P., Stampfli, G.M., 2014. Durbachites-Vaugnerites - a geodynamic marker in the central European Variscan orogen. Terra Nova 26 85-95.

Vroon, P.Z., Lowry, D., Van Bergen, M.J., Boyce, A.J., Mattey, D.P., 2001. Oxygen isotope systematics of the Banda Arc: low $\delta^{18} \mathrm{O}$ despite involvement of subducted continental material in magma genesis. Geochim. Cosmochim. Acta 65, 589-609.

Williams, H.M., Turner, S., Pearce, J.A., Kelley, S., Harris, N.B.W., 2004. Nature of the source regions for post-collisional, potassic magmatism in southern and northern Tibet from geochemical variations and inverse trace element modelling. J. Petrol. 45, 555-607.

Wittig, N., Baker, J.A., Downes, H., 2007. U-Th-Pb and Lu-Hf isotopic constraints on the evolution of sub-continental lithospheric mantle, French Massif Central. Geochim. Cosmochim. Acta 71, 1290-1311.

Woodhead, J., Hergt, J., Shelley, M., Eggins, S., Kemp, R., 2004. Zircon Hf-isotope analysis with an excimer laser, depth profiling, ablation of complex geometries, and concomitant age estimation. Chem. Geol. 209, 121-135.

Workman, R.K., Hart, S.R., 2005. Major and trace element composition of the depleted MORB mantle (DMM). Earth Planet. Sci. Lett. 231, 53-72.

Xiong, F., Ma, C., Wu, L., Jiang, H.a., Liu, B., 2015. Geochemistry, zircon U-Pb ages and $\mathrm{Sr}-\mathrm{Nd}-\mathrm{Hf}$ isotopes of an Ordovician appinitic pluton in the East Kunlun orogen: new evidence for Proto-Tethyan subduction. J. Asian Earth Sci. 111, 681-697.

Yin, J., Chen, W., Xiao, W., Yuan, C., Sun, M., Tang, G., Yu, S., Long, X., Cai, K., Geng, H., Zhang, Y., Liu, X., 2015. Petrogenesis of Early-Permian sanukitoids from West Junggar, Northwest China: implications for Late Paleozoic crustal growth in Central Asia. Tectonophysics 662, 385-397.

Zhao, Z.F., Dai, L.Q., Zheng, Y.F., 2013. Postcollisional mafic igneous rocks record crust-mantle interaction during continental deep subduction. Sci. Rep. 3, 3413. 